\title{
Integrated stratigraphy of the Priabonian (upper Eocene) Urtsadzor section, Armenia
}

\author{
Laura J. Cotton ${ }^{1}$, Elena Y. Zakrevskaya², Annique van der Boon ${ }^{3}$, \\ Gayane Asatryan ${ }^{4}$, Flora Hayrapetyan ${ }^{4}$, Arsen Israyelyan ${ }^{4}$, \\ Wout Krijgsman ${ }^{3}$, György Less ${ }^{5}$, Simonetta Monechi ${ }^{6}$, \\ Cesare A. Papazzoni ${ }^{7}$, Paul N. Pearson ${ }^{8}$, Anatoly Razumovskiy ${ }^{9}$, \\ Willem Renema ${ }^{1}$, Ekaterina Shcherbinina ${ }^{9}$, and Bridget S. Wade ${ }^{10}$
}

With 15 figures

\begin{abstract}
The transition from the Bartonian to the Priabonian, as traditionally understood, has long been associated with a series of extinctions and originations in several microfossil groups. The planktonic foraminifer genus Morozovelloides and large species of Acarinina suffered a rapid global extinction, as did many radiolarians. Calcareous nannofossils show several assemblage changes including the acme beginning of $\mathrm{Cr}$ brocentrum erbae and the lowest and highest occurrences of Chiasmolithus oamaruensis and C.grandis respectively. In shallow water environments, larger foraminifera also show an extinction among large species of Nummulites, as well as the first occurrences of the stratigraphically important genus Spiroclypeus. However, the correlation between shallow and deep water records remains uncertain, as do the mechanisms driving these biotic events. Here we present the results of a new integrated stratigraphical study (calcareous nannofossils, planktonic foraminifera, larger benthic foraminifera, and low-resolution magnetostratigraphy) of the Urtsadzor section in south-western Armenia which appears to be continuous through this interval. The Urtsadzor section consists of calcareous siltstones rich in micro- and nannofossils, with interbedded limestones containing abundant larger benthic foraminifera. Our new data enable us to correlate larger foraminiferal events with global plankton biostratigraphy, in a section outside of southwest Europe where most previous correlations have been based. At Urtsadzor, the large Nummulites species of N. millecaput-group are present throughout the whole section but decrease in abundance toward the top. The first occurrence of Spiroclypeus, also occurs in the upper part of the section, marking the SBZ 18/19 boundary. These events are associated with the phylogenetic development of the Nummulites fabianii and Heterostegina reticulata lineages. However, the calcareous plankton biostratigraphy indicates the section is well within the Priabonian; within plank-
\end{abstract}

\footnotetext{
Authors' addresses:

1 Corresponding author: Naturalis Biodiversity Center, PO Box 9517, 2300 RA Leiden, the Netherlands. Present address: School of Biological Sciences, The University of Hong Kong, Kadoorie Biological Sciences Building, Pokfulam Road, Hong Kong SAR, China. E-mail: ljcotton@hku.hk

2 Vernadsky State Geological Museum RAS, Mokhovaya 11, bl.11 Moscow 125009 Russia.

3 Fort Hoofddijk Paleomagnetic Laboratory, University of Utrecht, Budapestlaan 17, 3584 CD Utrecht, the Netherlands.

4 Institute of Geological Sciences, Armenian National Academy of Sciences, Yerevan, Armenia.

5 University of Miskolc, H-3515, Miskolc-Egyetemváros, Hungary.

6 Dipartimento di Scienze della Terra, Università di Firenze, Via LaPira 4, I50121 Firenze, Italy.

7 Dipartimento di Scienze Chimiche e Geologiche, Università di Modena e Reggio Emilia, Via Campi 103, 41125, Modena, Italy.

8 School of Earth and Ocean Sciences, Cardiff University, Main Building, Park Place, Cardiff CF10 3AT, U.K.

9 Geological Institute, Russian Academy of Sciences, 7 Pyzhevsky per., 119017 Moscow, Russia.

${ }^{10}$ Department of Earth Sciences, University College London, Gower Street, London, WC1E 6BT, U.K.
} 
tonic foraminiferal Zones E14 and E15 and calcareous nannoplankton Zones CNE 18 and CNE 19. These results indicate larger foraminiferal events occur well above the planktonic foraminiferal extinction level and nannofossil assemblage changes indicating the events are not synchronous across groups, with implications for biostratigraphy and recognition of the basal Priabonian in different depositional settings and regions.

Key words. biostratigraphy; Priabonian; foraminifera; nannofossils; Armenia

\section{Introduction}

The Bartonian-Priabonian transition is an important interval in the Eocene associated with widespread biotic turnover in the marine realm. However the boundary itself is not formally defined, and the marker defining the Global Stratotype Section and Point (GSSP) is currently under discussion. The Alano di Piave section in north-east Italy has been suggested as the type section due to its continuous outcrop, completeness, lack of deformation and ease of access, but the GSSP has not yet been placed (Agnini et al. 2011). At present, two criteria have been suggested for the formal placement of the Bartonian/Priabonian boundary, one lithological (Agnini et al. 2011) and the other biostratigraphical (Agnini et al. 2011, Wade et al. 2012).

A prominent ash layer known as the 'Tiziano bed' at $63.57 \mathrm{~m}$ in the Alano section was suggested by Agnini et al. (2011) as a possible level for placement of the GSSP as it is easily recognizable in the proposed section. The age is defined on magnetostratigraphic correlations and ranges from 37.814 to $37.521 \mathrm{Ma}$ depending on the scale used (Agnini et al. 2011). This proposal also takes into account current biostratigraphical practices which place the extinction of the large muricate planktonic foraminifera Acarinina and Morozovelloides within the Bartonian while the nannofossil Isthmolithus recurvus and larger benthic foraminifera Nummulites fabianii would be confined to the Priabonian (Agnini et al. 2011). An alternative proposal by Wade et al. (2012) places the GSSP at the last occurrence horizon of the large muricate planktonic foraminifera Morozovelloides which is very close to, but slightly above, the extinction of the large acarininids. These levels have been widely used in global biostratigraphic schemes (Blow 1969, Toumarkine and Luterbacher 1985, Wade 2004, Berggren and Pearson 2005, Wade et al. 2011). The muricate extinction levels are robust; synchronous across the Atlantic Ocean (Wade 2004, 2012, Agnini et al. 2011) and the double extinction occurs within an $11 \mathrm{kyr}$ interval, enabling completeness of sedimentary records to be assessed. The levels additionally correspond closely to a radiolarian turnover and are within the short magneto-subchron C17n.3n, providing potential correlations to non-calcareous sediments. In the Alano section the proposed boundary level is recognised with the last occurrence of Morozovelloides crassatus at $57.62 \mathrm{~m}, 5.95 \mathrm{~m}$ below the 'Tiziano bed'. In addition to being a biostratigraphic marker the muricate planktonic foraminiferal extinctions mark a major change in ecology in the surface oceans (Wade et al. 2008), with extinctions in radiolarians (Kamikuri and Wade 2012) and a slower overturning in calcareous nannofossils (Newsam et al. this volume).

Major changes also took place in the shallow marine realm at a level somewhere near the base of the Priabonian as traditionally interpreted. Larger benthic foraminifera (LBF) suffer a series of extinction events from middle to upper Eocene, including a large overturning event that has been taken to represent the Bartonian/ Priabonian boundary in LBF biostratigraphy (Hallock et al. 1991, Papazzoni and Sirotti 1995, Serra-Kiel et al. 1998, Bassi et al. 2000, Luciani et al. 2010, Less et al. 2008, Less and Özcan 2012). However, the mutually exclusive environments of planktonic foraminifera and LBF, together with possible species migration and endemism, mean that regional schemes are used and correlating this event precisely with global stratigraphy is difficult. The Tethyan Shallow Benthic Zonation (SBZ) is the best defined of the larger foraminiferal schemes. The Priabonian was originally defined (Munier-Chalmas and de Lapparent 1893) in the type section of Priabona (northern Italy), which contains Nummulites fabianii close to its base. Therefore, the appearance of $N$.fabianii was subsequently used to mark the base of the Priabonian in LBF stratigraphy. This use was maintained by Serra-Kiel et al. (1998) in the construction of the SBZ. The boundary between SBZ 18 and SBZ 19 is thought to correlate with the broad Bartonian-Priabonian transition interval and is defined by the last occurrence of the largest species of Nummulites (N. millecaput-maximus, N. perfortatus-biedai and $N$. gizehensis-lyelli groups) along with the first occurrence of the genus Spiroclypeus and the transition in the reticulate Nummulites (a distinctive group of Nummulites with a mesh-like ornamentation) from N.hormo- 


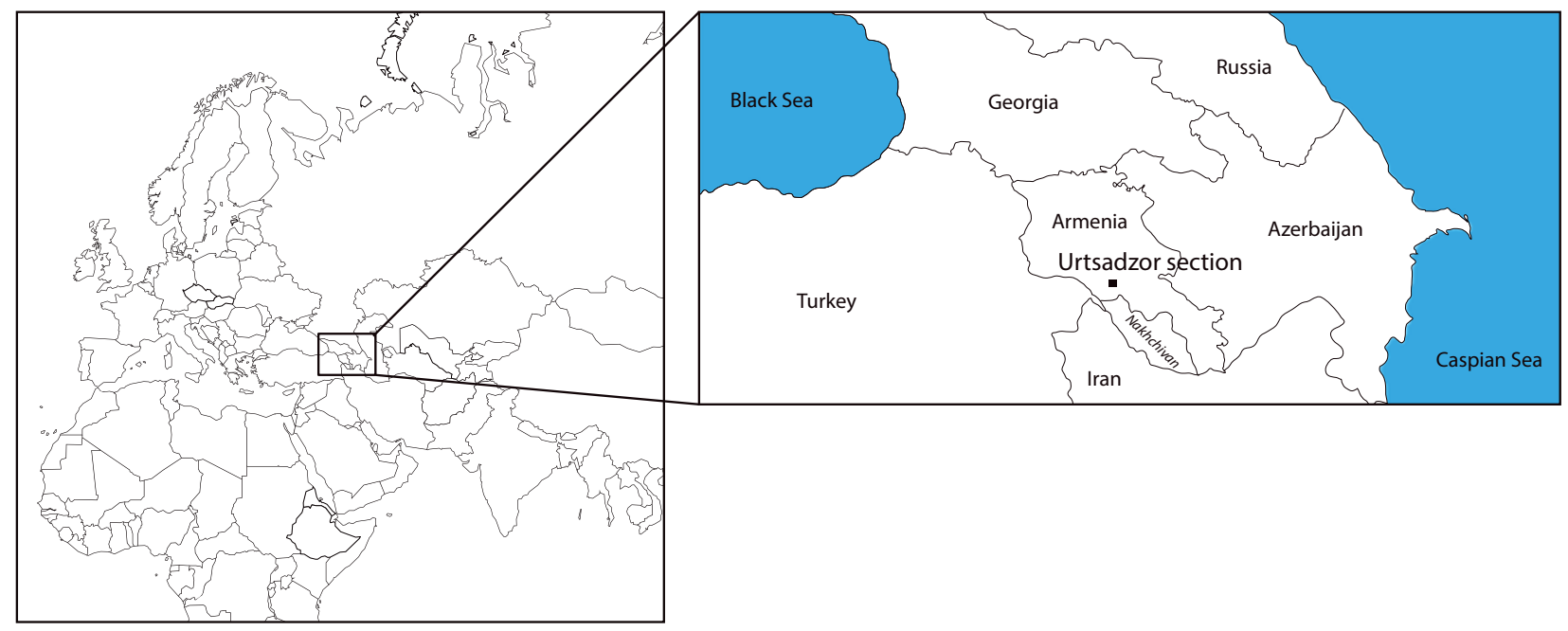

Fig. 1. Location map showing Armenia and the Urtsadzor section.

ensis (=N.ptukhiani sensu Schaub, 1981, “N.ptukhiani" in Papazzoni 1998) to N. fabianii (Papazzoni and Sirotti 1995, Serra-Kiel et al. 1998, Less et al. 2008, Less and Özcan 2008, 2012, Costa et al. 2013). However, a lack of independent dating means the exact correlation between the SBZ 18/19 boundary and global stratigraphy remains uncertain.

The Urtsadzor section in south-western Armenia (Fig. 1) contains an apparently complete succession reported to span the SBZ 18/19 boundary with both LBF and calcareous plankton (Krasheninnikov et al. 1985, Krasheninnikov and Ptukhian 1986, Zakrevskaya et al. 2014). The dominant lithology is pelagic calcareous siltstone, rich in micro- and nannofossils, interbedded with resedimented limestones containing abundant LBF. Here we report integrated stratigraphy (calcareous nannofossils, planktonic foraminifera, LBF, and magnetostratigraphy from the same sample set) using updated taxonomic and biostratigraphic schemes enabling us to easily compare results with other sections and improve the correlation between LBF events and global planktonic biostratigraphy. Additionally, this study contributes new data on shallow water environments to the discussion on where to place the Bartonian/Priabonian boundary marker.

\section{Geological setting}

Armenia is located in the central part of the TauroCaucasian segment of the Alpine-Himalayan belt in an area of collision between the Eurasian and Arabian plates (Fig. 1-3; Sosson et al. 2010, Aghamalyan et al.
2012). During the Paleogene it was within the northern part of the Tethys basin, open to the Central Iranian and Mesopotamian seas, but separated from the wide Peri-Tethyan basin by the large east-west trending Caucasian island and was relatively shallow, with LBF commonly occurring. During this period sedimentation could be broadly divided into two depositional regimes; the north of Armenia belonged to the active margin of the Eurasian plate and thus consists of largely volcanic-sedimentary and volcanic rocks, whilst the south Armenia belonged to the passive margin of Gondwanian plate and carbonates, carbonate-terrigenous and tuffaceous sediments were deposited ( $\mathrm{Za}-$ krevskaya et al. 2014).

Paleogene marine sediments are therefore widely known from southern Armenia, cropping out across a region to the south of Yerevan known as the Arax Structural-Facial Zone. This includes the Azatek, Shagap, Vedi and Landzhar areas (Fig. 3). The middle-upper Eocene lower Oligocene sediments are formally defined as the Arpa Formation (Lutetian), Azatek Formation (Bartonian), Zovashen (in the Yerevan region) - Chimankend Formations or Carbonate Clayey Unit (in the Vedi-Yekhegnadzor regions; BartonianPriabonian) and Shoragbyur (in the Yerevan region) Shagap (in the Vedi region) - Malishka Formations (in the Yekhegnadzor region; lower Oligocene) (Gabrielyan 1964, Veguni 1964, 1978, Krasheninnikov et al. 1985). The Zovashen/Chimankend Formation spans the uppermost Bartonian and Priabonian, comprising marls and nummulitic limestones, and crops out in the Urtsadzor region where a number of micropalaeontological studies have been carried out since the 1950s 


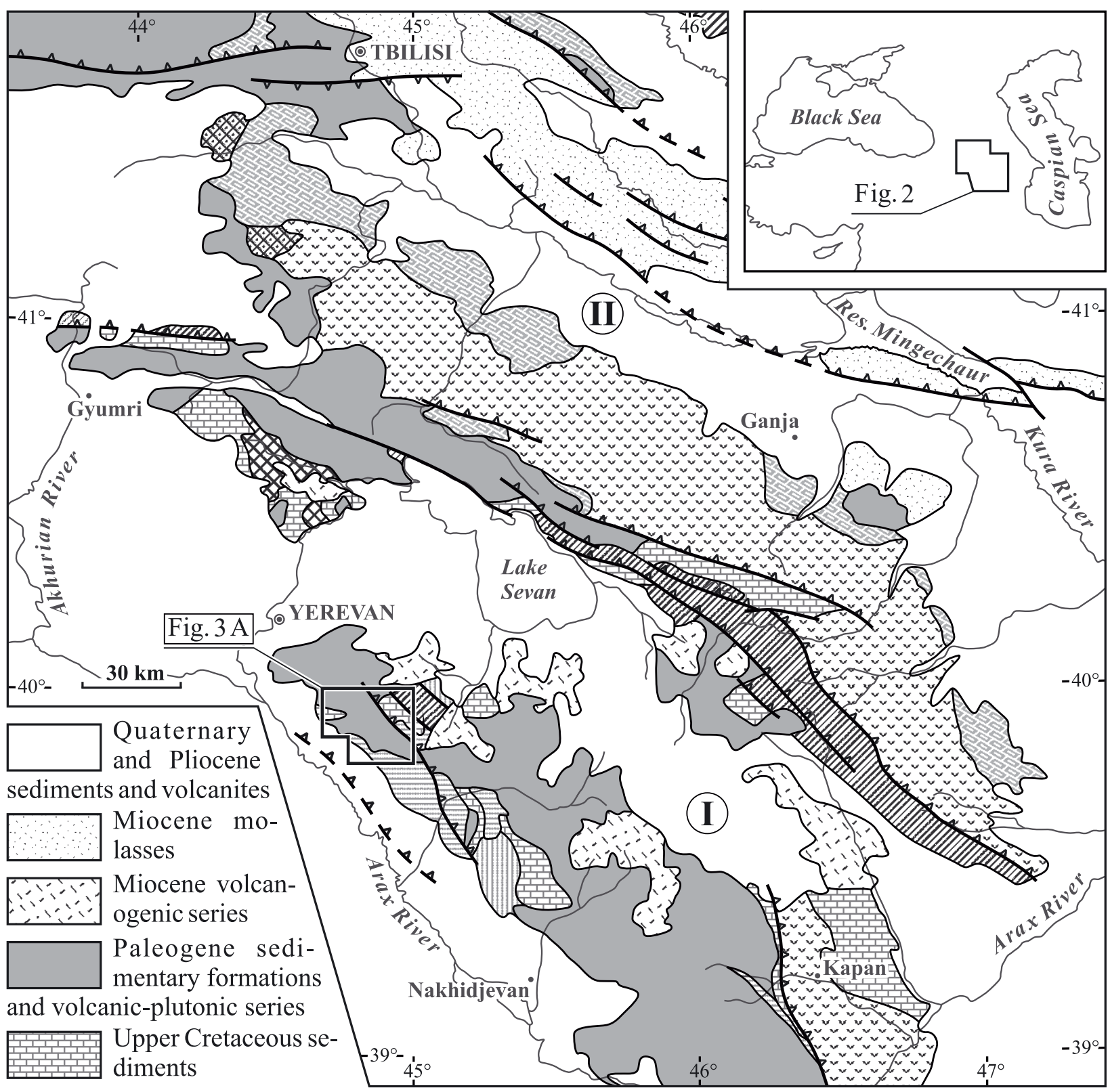

\section{(I) South Armenian Block}

Triassic to Middle Jurassic sediments and alkaline volcanites

Devonian to Permian sedimentary cover

Proterozoic metamorphic basement

\section{Sevan-Akera Suture Zone}

Middle Jurassic to Lower Cretaceous Ophiolitic suites and volcanic-sedimentary associate complexes

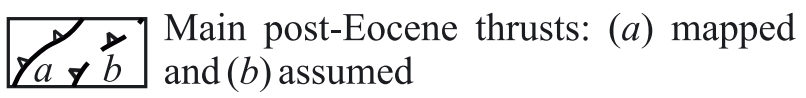

(II)

Eurasian Margin: Greater Caucasus and Somkheto-Karabakh Island Arc Lower Cretaceous (Albian) to Upper Cretaceous sediments

Jurassic sediments of Greater Caucasus (Bajocian) to Upper Jurassic volcanic-plutonic series of Somkheto-Karabakh Island Arc

Variscan basement and Carboniferous sedimentary formations

(a) other faults and (b) geological boundary of various nature 


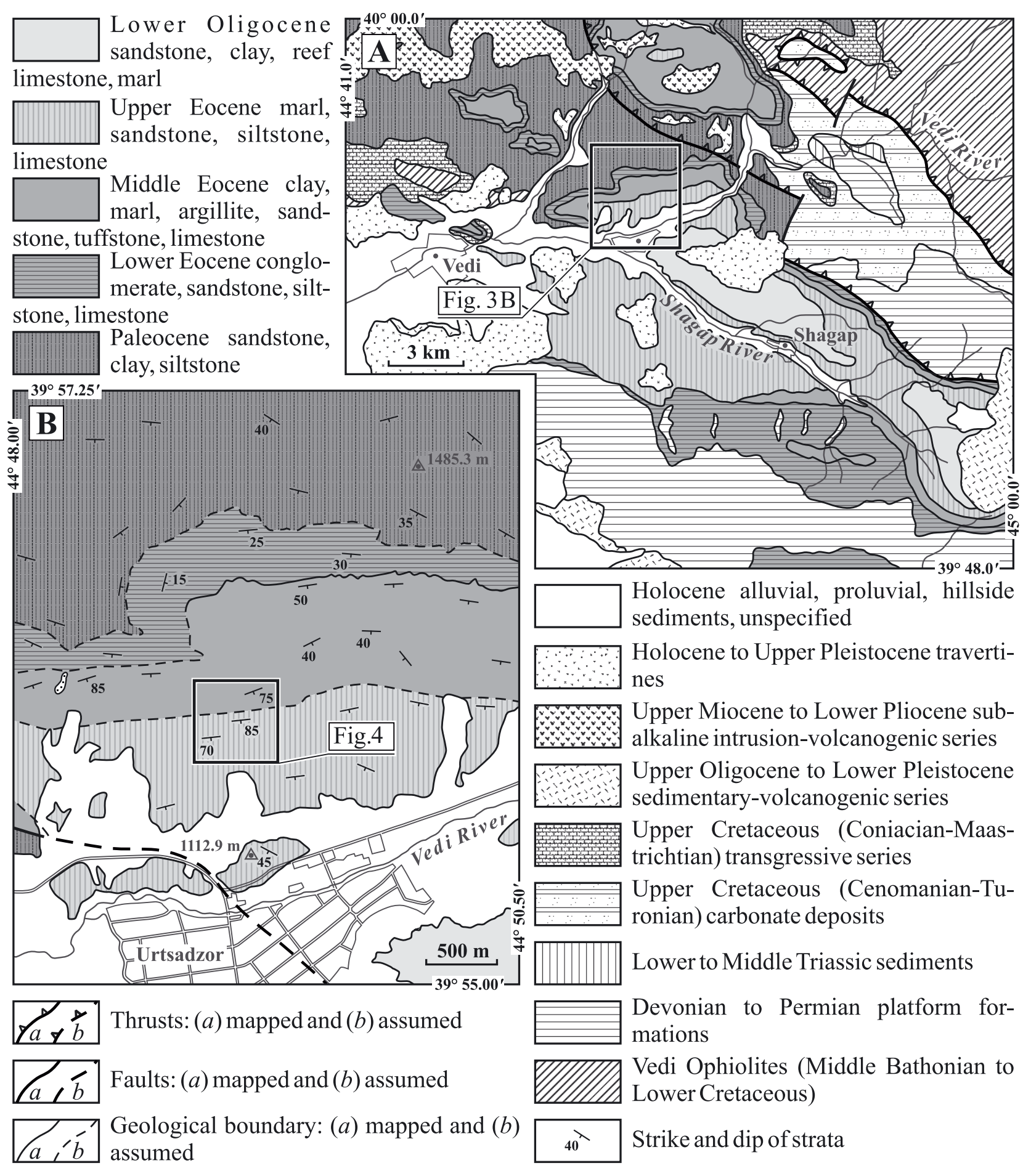

Fig. 3. Detailed geological maps of the studied area: A) Geological sketch map of basin inVedi region. Modified from Avetisyan et al. (2004). All coordinates in this and other schemes are in WGS'84. The Baltic sea levels System of altitude is used. B) Geological sketch map of Paleogene deposits in studied area. Modified after Avanesyan et al. (2004) and Avetisyan et al. (1961).

Fig. 2. Regional geological map of Armenia and the Transcaucasian region, modified after Sosson et al. (2010). 
(see summary, Fig. 5). Studies of planktonic foraminifera by Krasheninnikov et al. (1985) assign the formation to the Globigerinatheka semiinvoluta, Globorotalia cocoaensis and Turborotalia centralis Zones of the Crimean-Caucasus scheme (Krasheninnikov and Ptukhian 1986). More recently Hayrapetyan and Zakrevskaya (2013) assign it to the Globigerinatheka semiinvoluta, T. cocoaensis - G. index, T. cunialensis H. alabamensis Zones of the Armenian scheme, which correlate to planktonic foraminiferal Zones P15, P16 and P17 of Berggren et al. (1995) and the E14-E16 interval of Berggren and Pearson (2005) and Wade et al. (2011). The base of Zone E14 is difficult to identify in Armenia because of the rarity of the zone fossil Morozovelloides crassatus (= Morozovella spinulosa of authors; Krasheninnikov and Ptukhian 1973, Krasheninnikov et al. 1985, Krasheninnikov and Ptukhian 1986). Larger benthic foraminifera are reported from interbedded resedimented limestones throughout the formation, with Nummulites and orthophragmine-rich limestones. The basal bed is referred to as the 'Nummulites millecaput horizon' due to the abundance of the Nummulites millecaput-group at this level and in its upper parts orthophragmine limestones with rare representatives of the Nummulites millecaput-group occur (Gabrielyan 1964, Grigorian 1979, Krasheninnikov et al. 1985, Grigorian 1986). The formation is the- refore assigned to the SBZ 18 and SBZ 19 in LBF stratigraphy (Zakrevskaya et al. 2014).

\section{Materials and methods}

The Urtsadzor section was visited in 2014 as part of an international effort to improve the correlation of the LBF biostratigraphy with global stratigraphic records, and due to its relevance to the Bartonian/Priabonian boundary discussion. Preliminary investigations by E.Z and F.H. indicated that the site is continuous across the SBZ 18/19 boundary within the Zovashen Formation. The section is a $155 \mathrm{~m}$ thick hillside exposure approximately $1 \mathrm{~km}$ north of Urtsadzor village and the Vedi-Landzar road (GPS $39^{\circ} 55.943 \mathrm{~N}$ and $44^{\circ} 49.079 \mathrm{E}$; all co-ordinates are given in WGS '84), crossing the northern slope of the large Shagap syncline (Figs. 3 and 4 ).

The succession comprises of a series of greyish brown calcareous siltstones with allochthonous limestone beds rich in LBF interbedded throughout the succession (see Fig. 5). The limestones are packstones in beds up to $1 \mathrm{~m}$ thick and in most cases are largely comprising LBF bioclasts along with red algae, echinoderm fragments and smaller benthic foraminifera. Large corals, echinoderms and bivalve specimens are common

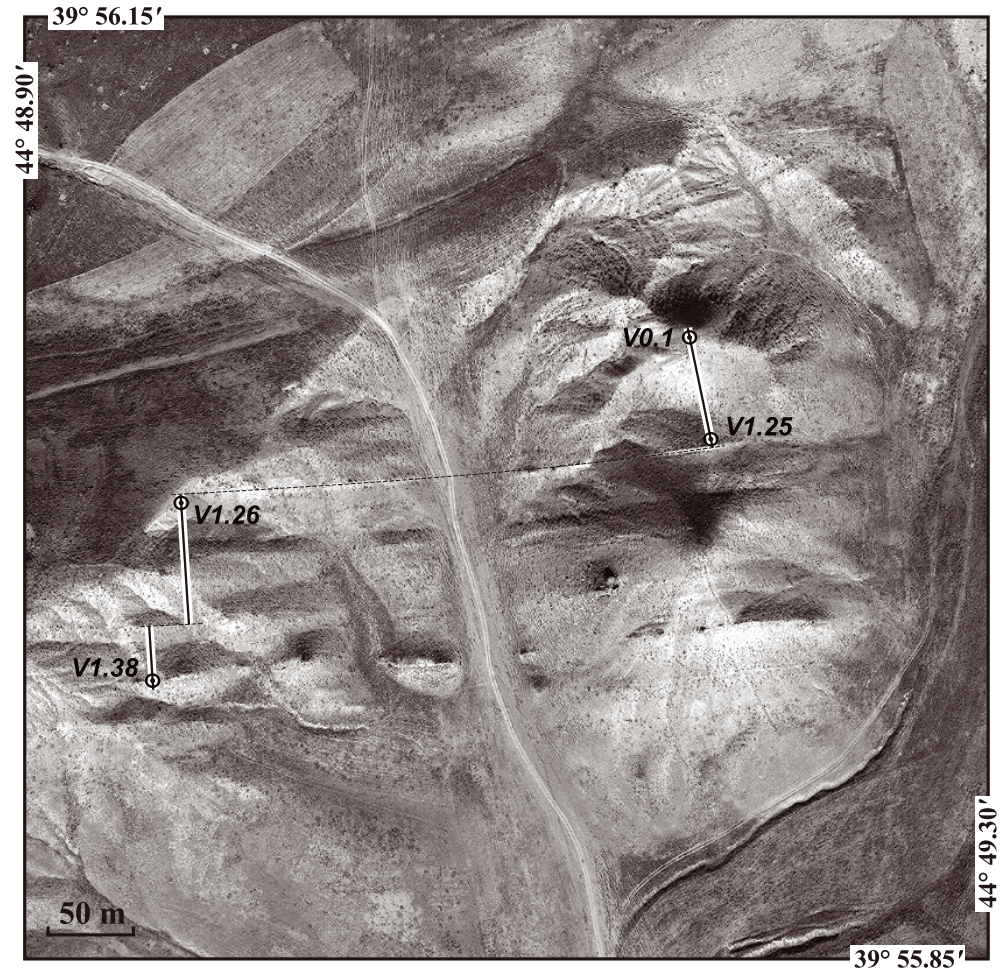

Fig. 4. Location of the studied Priabonian section in the Urtsadzor area. 


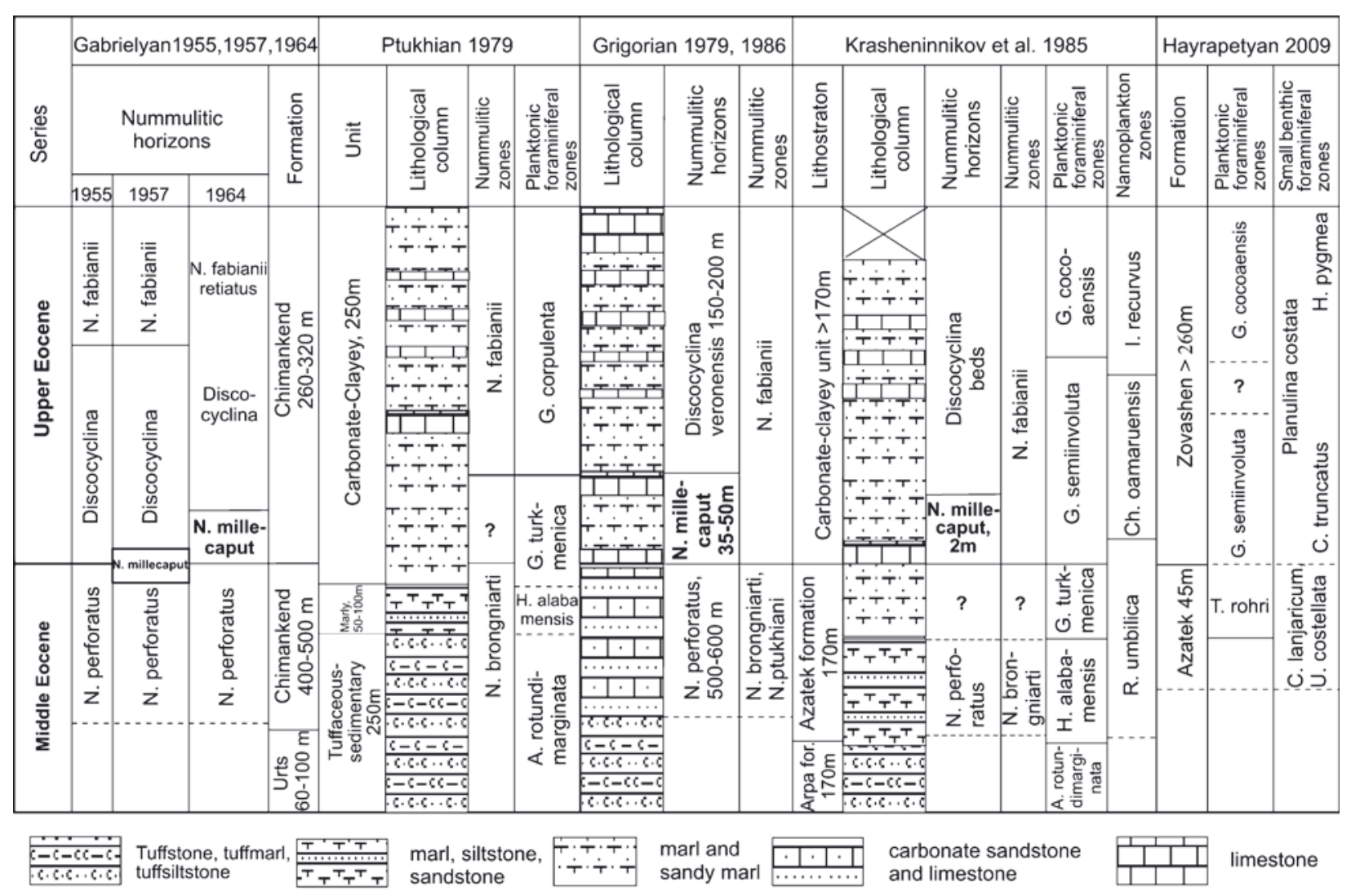

Fig. 5. Summary diagram showing previous work on the larger benthic foraminiferal, planktonic foraminiferal and nannofossil biostratigraphy in the Urtsadzor region.

in bed V1.38. In outcrop LBF are oriented approximately horizontally, and in thin section fragments and sutured grain boundaries are common. This indicates LBF were redeposited as uncemented grains, ruling out the possibility of subarial exposure and redeposition. Some size sorting is also visible in outcrop, with larger specimens tending to be towards the base of beds. The surfaces are generally friable and LBF are easily collected from these levels; large Nummulites and orthophragmines are particularly visible in outcrop. The exception to this general description is sample V1.30, which is a harder pack-grainstone, with a much larger amount of matrix and rarer small sized LBF.

The lower part of the succession (samples V0.1 to V1.25) was sampled on the eastern side of the earth road and dry brook valley, and the upper part (samples V1.26 to V1.38) on the western side, where the exposure was better. Correlation across the small valley was possible due to the prominent limestone bed at the V1.25 level (see Fig.4). Planktonic foraminiferal and nannofossil samples were taken from the siltstone at approximately $2-3 \mathrm{~m}$ intervals. Holes of approximately $1 \mathrm{~m}$ depth were dug to avoid alteration from surface weathering for samples of planktonic foraminifera, nannofossils and palaeomagnetic studies. The LBF samples were collected from the limestone levels and surrounding weathered out material for obtaining oriented sections (see Fig. 6 for sampled levels).

\subsection{Planktonic foraminifera}

Thirty-five samples have been investigated for planktonic foraminiferal content. Samples were boiled with dilute hydrogen peroxide and washed over a $63 \mu \mathrm{m}$ sieve. Due to variable preservation, analyses were restricted to presence/absence of species. Preservation was moderate to poor, with tests commonly recrystallized and always infilled with carbonate, making the material unsuitable for species-specific stable isotope stratigraphy. Preservation was especially poor in samples taken close to the limestone beds (e.g. V1.11, 16, 18, 24 and 26), and one sample was barren (V1.36). All other samples were preserved well enough to identify the range of species present. No evidence of reworking was detected. Taxonomy follows Pearson et al. (2006). Ages cited are based on the timescale of Cande and Kent (1995). 


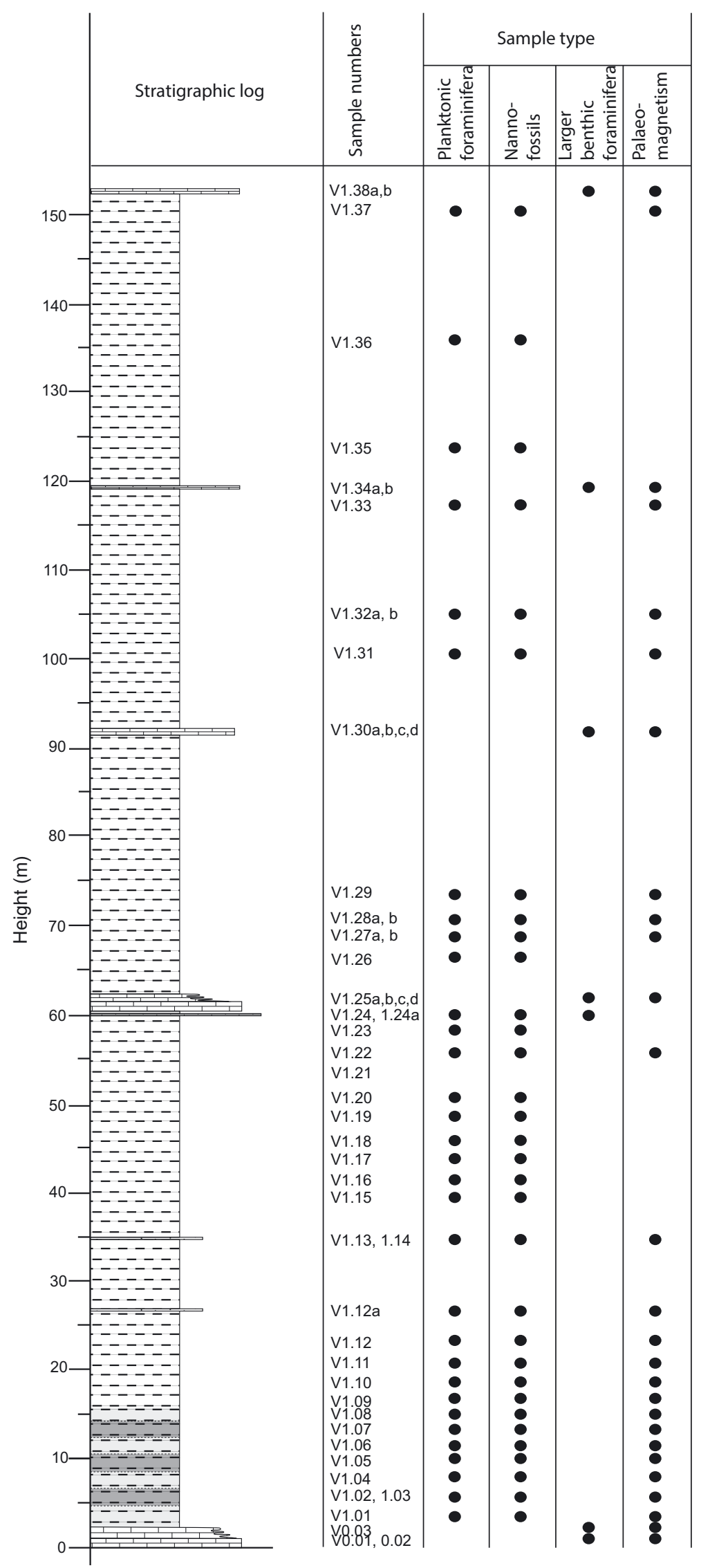

Fig.6. Stratigraphic log of section showing sampled levels and sample types. 


\subsection{Nannofossils}

Thirty-six samples have been investigated for calcareous nannofossil content. The samples were prepared from unprocessed materials as smear slides using standard techniques (Bown and Young 1998) and analysed under a light microscope at $1000 \times$ magnification. Qualitative and semi-quantitative analyses were performed in order to determine the presence of biostratigraphically important species. Three or more random traverses were analysed to detect rare key species. Counts of selected genera and species (Discoaster, Sphenolithus, reticulofenestrids, a.o.) were made versus total assemblage taking into account 100 random fields of view (f.v.). The specimens of Chiasmolithus preserved as a half or more and segments of discoasters larger than a quarter were included in the counting process. Nannofossil abundance and preservation varies significantly across the studied part of section. The total abundance (number of coccoliths per f.v.) varies from abundant to common $(>40$ to $>20$ specimens per f.v.), but in samples from V1.04 to V1.08 and sample V1.23, close to the $N$. millecaput rich limestone, the total abundance drops to $<20$ per f.v., but only sample V1.30 is barren. Preservation of the nannofossils varies from poor to moderate, improving in the uppermost part of section studied. Few reworked upper Cretaceous and Paleocene-Eocene taxa have been found throughout the section, and occur mainly in the lower and middle parts of the section. Taxonomy follows Perch-Nielsen (1985) and Fornaciari et al. (2010) for Cribrocentrum and Dictyococcites.

\subsection{Larger benthic foraminifera}

Seven sampled levels have been investigated for larger benthic foraminiferal assemblages, all are limestone beds. Both the consolidated limestones and loose specimens from the friable surfaces and immediately below the beds were collected. The limestones were prepared as petrological thin sections and individual specimens were prepared as oriented individual sections (equatorial and axial) by grinding with fine sandpaper or by splitting them with pliers. Preservation of specimens was generally moderate, with specimens infilled with calcite but features easily visible in thin section. Due to the variation in sample size and collection method, whether loose specimens or solid limestone was collected, presence/absence data have been used with qualitative abundances noted in specific instances. Taxonomy follows Schaub (1981), Hottinger et al. (2001) and Less (1987).

\subsection{Palaeomagnetism}

A total of 39 samples were taken from the Urtsadzor section for palaeomagnetic analyses. Conventional palaeomagnetic core plug samples $(25 \mathrm{~mm}$ diameter cores) were drilled, using a gasoline-powered drilling machine. Samples were subsequently oriented by a compass. All samples were cut in the lab to same sized specimens $(22 \mathrm{~mm})$. The samples were subjected to thermal and/or alternating field demagnetisation. Temperature increments of $20-60^{\circ} \mathrm{C}$ were applied to thermally demagnetise the samples in a shielded furnace, to a maximum temperature of about $400^{\circ} \mathrm{C}$. This temperature is chosen to avoid thermal alteration during heating of the samples. Some samples were demagnetised by alternating field demagnetization. These samples were demagnetised stepwise, applying steps of $5 \mathrm{mT}$. The natural remanent magnetisation (NRM) and subsequent remanence values after each demagnetisation step were measured on a $2 \mathrm{G}$ Enterprise horizontal cryogenic magnetometer equipped with three DC SQUIDS (noise level $3 \times 10-12 \mathrm{Am}^{2}$ ). NRM directions were determined using principal component analysis (Kirschvink 1980) and the results were plotted in orthogonal demagnetisation plots (Zijderveld 1967) using Palaeomagnetism.org (Koymans et al. 2016). Declination and inclination angles were calculated. Mean directions were determined for subsections using standard Fisher statistics.

The magnetic susceptibility of all samples was measured at room temperature, using the AGICO KLY3 Kappabridge. Measured values for the susceptibility were normalised to the mass of the samples. Variations in climate, environment, or detrital input (Hay 1998, 1996, Ellwood et al. 2000), might cause changing diagenetic conditions (e.g. Da Silva et al.2012), reflected in changes in lithology throughout a section, resulting in differences in susceptibility.

Thermomagnetic runs were carried out on samples of different lithology, to asses magnetic carriers. These analyses were performed in air, using a modified horizontal translation Curie balance (Mullender et al. 1993). Samples were powdered, and magnetisation was measured as a function of temperature during six heating and cooling cycles, up to increasingly elevated temperatures $\left(700^{\circ} \mathrm{C}\right.$ maximum; heating and cooling rate $10^{\circ} \mathrm{C} / \mathrm{min}$ ). 


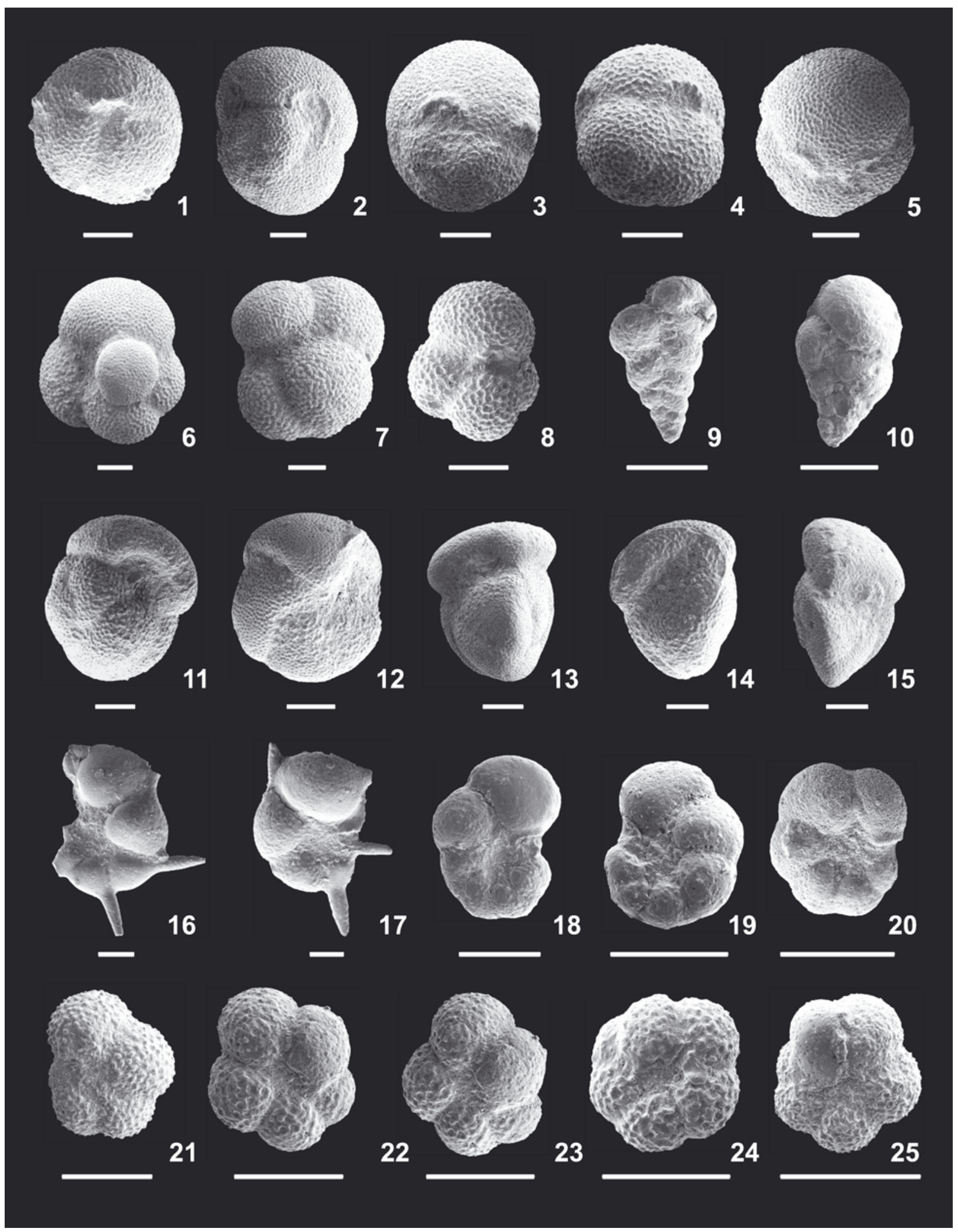




\section{Results}

\subsection{Planktonic foraminiferal biostratigraphy}

The standard subtropical planktonic foraminiferal zonation of Wade et al. (2011), with additional data from Berggren and Pearson (2005, Table 1) was used in this study. The planktonic foraminiferal assemblages are diverse, typical of subtropical pelagic environments, except for the rarity of the genus Hantkenina (Pearson et al. 2006). Common components include several species of Subbotina, Turborotalia, Globigerinatheka, Dentoglobigerina and Pseudohastigerina. Other taxa present are Parasubbotina hagni, Globigerina officinalis, Catapsydrax unicavus, C. dissimilis, Globorotaloides spp., small Acarinina spp. (<300 micron), Turborotalita quinqueloba, Chiloguembelina and Streptochilus (Figs. 7 and 8).

The top of G. semiinvoluta is between Samples V1.28 and V1.29. From the base of the section to that level (Sample V1.1 to V1.28a) samples are assigned to Globigerinatheka semiinvoluta Highest Occurrence Zone (HOZ) (Zone E14). The top of the section (Samples V1.29 to V1.37) is assigned to the Globigerinatheka index HOZ (Zone E15; see Fig. 8). A summary of biostratigraphic constraints is as follows:

The large muricate planktonic foraminifera (Morozovelloides and Acarinina $>300 \mu \mathrm{m}$ ) are highly distinctive. There were no large muricate planktonic foraminifera found within the sampled section, only small acarininids which are known to continue into the late Eocene and Oligocene (Wade 2004, Berggren et al. 2006, Luciani et al. 2010, Pearson and Wade 2015). The top of Morozovelloides crassatus marks the base of the Globigerinatheka semiinvoluta HOZ Zone (Zone E14), and has been calibrated to $38.0 \mathrm{Ma}$ in Subchron C17n.3n at ODP Site 1052 in the western North Atlantic Ocean (Wade 2004) and in the Alano
Section, Italy (Wade et al. 2012). The entire section is therefore stratigraphically higher than this.

Globigerinatheka semiinvoluta is a highly distinctive species characterised by an inflated final chamber with two to three circular (porthole) rimmed apertures along the suture at the base of the final chamber (Premoli Silva et al.2006). It occurs in the section with the closely related G. mexicana and G. tropicalis. It is present continuously varying from rare to frequent, from the base of the section Sample V1.1 to Sample V1.9, then sporadically to its Top in Sample V1.28a. The Base of G. semiiinvoluta has been calibrated to 38.0 Ma near the top of subchron C17n. 3n, at a slightly higher level than the Top of M.crassatus at ODP Site 1052 by Wade (2004). Samples from V1.29 upwards were carefully searched but failed to yield any specimens of G. semiinvoluta. The top of G. semiinvoluta has been calibrated at the Massignano stratotype section, Italy, to within subchron $\mathrm{C} 16.2 \mathrm{n}$ by Coccioni et al. (1988) and refined by Berggren and Pearson (2005) with a calibrated age of $35.8 \mathrm{Ma}$.

The zonal marker Globigerinatheka index, the top of which marks the base of the Hantkenina alabamensis HOZ (Zone E16), occurs sporadically and rarely throughout the section, including the topmost sample in the section (Sample V1.38), confirming that the top of the section is within Zone E15. The top of G.index was calibrated in the Massignano section at $34.3 \mathrm{Ma}$ within Chron C13r by Berggren and Pearson (2005).

Additional biostratigraphic information is provided by morphospecies within the evolving Turborotalia cerroazulensis lineage. Detailed morphometric analyses from ODP Site 865 in the Pacific Ocean has shown that the Base of T.cocoaensis and T.cunialensis and the Top of T.pomeroli are all part of a gradual evolutionary trend within a single evolving lineage (Pearson et al. 2006), hence their documentation is fairly subjective. The morphospecies are divided mainly on the peripheral angle of the final chamber in edge view (Pe-

Fig. 7. Planktonic foraminifera from the Urtsadzor section. 1 - Globigerinatheka mexicana (Cushman), Sample V1.2; 2 Globigerinatheka tropicalis (Blow and Banner), Sample V1.2; 3-4 - Globigerinatheka semiinvoluta (Keijzer), Sample V1.2; 5 - Globigerinatheka semiinvoluta (Keijzer), Sample V1.27; 6 - Subbotina corpulenta (Subbotina), Sample V1.2; 7 Subbotina gortanii (Borsetti), Sample V1.32; 8-Dentoglobigerina galavisi (Bermudez), Sample V1 .2; 9 - Chiloguembelina ototara, Sample V1.27; 10 - Streptochilus globigerum, Sample V1.27; 11 - Turborotalia pomeroli (Toumarkine and Bolli), Sample V1.2; 12 - Turborotalia cerroazulensis (Cole), Sample V1.27; 13-14 - Turborotalia cerroazulensis (Cole), Sample V1.2; 15 - Turborotalia cocoaensis (Cushman), Sample V1.2; 16 - Hantkenina primitiva (Cushman and Jarvis), Sample V1.20; 17 - Hantkenina alabamensis Cushman, Sample V1.24; 18-19 - Pseudohastigerina micra (Cole), Sample V1.2; 20 - Pseudohastigerina naguewichiensis (Myatliuk), Sample V1.27; 21 - Acarinina medizzai (Toumarkine and Bolli), Sample V1. 27; 22-25 - Turborotalita quinqueloba (Natland), Sample V1.24b. Scale bar $=100 \mu \mathrm{m}$ 


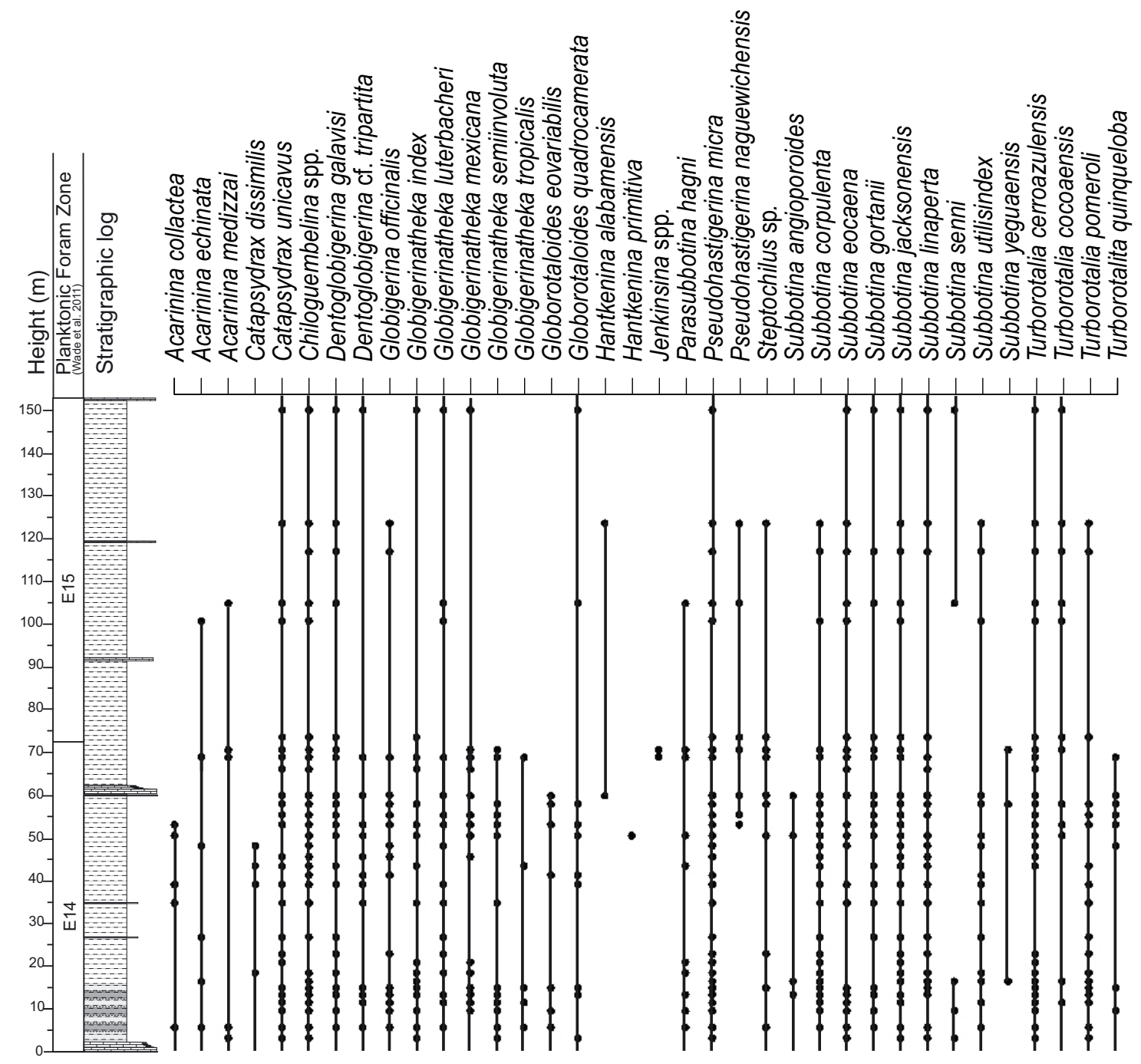

Fig. 8. Planktonic foraminiferal range chart, lines show interpolations between observed occurrences (dots).

arson et al. 2006 and references therein). The Base Common Occurrence (BCO) of Turborotalia cocoaensis is between Samples V1.19 and V1.20 although small single specimens were found below this in Samples V1.6 and V1.9. The HO of T. pomeroli was found between Samples V1.35 and V1.37 (Sample V1.36 being barren of planktonic foraminifera). The Base of T. cunialensis was not found in this section. These identified events have been calibrated at 35.7 and 35.3 Ma respectively at Massignano by Coccioni et al. (1988) and Berggren and Pearson (2005). At face value these ages suggest that the upper part of the Urtsadzor section is very expanded.

The Base of Pseudohastigerina naguewichiensis is between Samples V1.20 and V1.21. Pseudohastigerina naguewichiensis is relatively consistently present from Sample V1.21 to the top of the section. It is re- cognised by its small size, evolute coiling and circular periphery (Olsson and Hemleben 2006). Some specimens appear closely intergrading with P. micra, confirming that species as the likely ancestor (e.g. Pearson et al. 2006). Olsson and Hemleben (2006) placed the base of P. naguewichensis at the base of Zone E15 (i.e. coincident with the top of G. semiinvoluta), but we find it at a slightly lower level, in the upper part of Zone E14. There is as yet no formal calibration.

\subsection{Calcareous nannofossil biostratigraphy}

The calcareous nannofossil zonal schemes used for the Eocene are the "standard" zonations of Martini (1971) codified as NP, Okada and Bukry (1980) codified as $\mathrm{CP}$, and the recent biozonation of Agnini et al. (2014) 


\begin{tabular}{|c|c|c|c|c|c|}
\hline 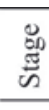 & $\begin{array}{c}\text { Okada\& } \\
\text { Bukry, } \\
1980\end{array}$ & $\begin{array}{c}\text { Martini, } \\
1971\end{array}$ & Nannofossil markers & $\begin{array}{c}\text { Agnini et al. } \\
2014\end{array}$ & Primary and secondary nannofossil markers \\
\hline \multirow{2}{*}{ 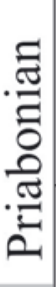 } & CP15b & NP19 & & CNE19 & $\checkmark$ B Cribrocentrum isabellae \\
\hline & CP15a & ND18 & $\checkmark$ B Isthmolithus recurvus & CNE18 & $\begin{array}{l}\quad \text { Bc Isthmolithus recurvus } \\
\text { Tc Cribrocentrum erbae } \\
\leftarrow \text { Istholithus recurvus SPIKE }\end{array}$ \\
\hline & & 1010 & $\begin{array}{l}\text { T Chiasmolithus grandis } \\
\text { B Chiasmolithus oamaruensis }\end{array}$ & CNE17 & $\longleftarrow^{\mathrm{T}}$ Chiasmolithus grandis \\
\hline \multirow{2}{*}{ 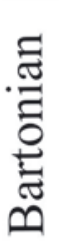 } & CP14b & NP17 & & CNE16 & \\
\hline & CP14a & NP16 & $\begin{array}{l}\text { T Chiasmolithus solitus } \\
\text { T Discoaster bifax }\end{array}$ & CNE15 & \\
\hline
\end{tabular}

Fig. 9. Correlation of the middle-upper Eocene nannofossil zonations and biohorizons.

codified as CNE based on integrated classical biohorizons and new bioevents using semi-quantitative counting methods (Fig.9). Besides the marker species, several secondary biostratigraphic events have been suggested and characterise the middle-upper Eocene interval (Fornaciari et al. 2010). Although the investigated Urtsadzor section shows common to abundant calcareous nannofossils, unfortunately, the rarity and discontinuous occurrence of index species makes the biostratigraphic definition difficult.

Throughout the studied succession nannofossil assemblages are dominated by placoliths, in particular Reticulofenestra, Cyclicargolithus floridanus, Coccolithus and Dictyococcites and nannoliths as Lanternithus minutus and Zygrablithus bijugatus that are commonly present (Figs. 10 and 11). Helicosphaera (mostly H.compacta) and Bicolumnus ovatus are continuously present in relatively low abundance. Discoaster, warm water indicators (Edwards, 1968, Bukry 1973, Monechi et al. 2000, Bralower 2002), are mainly composed by D.barbadiensis, D. saipanensis (rosetteshaped discoasters), D.tani, D. nodifer and secondly D. deflandrei. Sphenolithus, another warm-water indicator (Aubry 1992, Monechi et al. 2000, Bralower 2002), is represented mostly by common S. moriformis while $S$. predistentus, S. radians and S. pseudoradians are very rare. Large reticulofenestrids (Reticulofenestra umbilicus and $R$. hillae) are present from the base of the section with variable abundance, while Dictyococcites shows common occurrence. At the same time, reticulofenestrids are represented in rather high species diversity. Both taxa, Reticulofenestra and Dictyococcites, show significant intraspecific morphological modifications incorporating wide variations in coccolith size and shape. This sometimes makes species definition difficult. Chiasmolithus is exceptionally rare in the succession and often represents a minor component of the assemblages both at middle and low latitudes (Bukry 1981, Wei and Wise Jr. 1990). The zonal markers and the most commonly occurring species are shown in Fig. 10.

The events identified in the studied succession are as follows: The Base of Isthmolithus recurvus is the marker of the lower boundaries of NP19 Zone and CP15b Subzone. However, an earlier first rare occurrence of this species was recently shown in some sections within Spain and Egypt in the late Bartonian interval (Costa et al. 2013, Strougo et al. 2013). A temporary and short-lived occurrence of I. recurvus has been reported in Chron $17 \mathrm{n}$ followed by an absence interval prior to the re-entry of continuous (Base common $=$ Bc) I. recurvus, which falls in the middle of CNE18 (Agnini et al. 2014 and references therein). In the Urtsadzor section, I. recurvus occurs from the base of the section, it is sporadically present up to the level of sample V1.31 and then occurs continuously to the top of the section (Fig. 11). This supports the interpretation that the base of the section corresponds to NP19, $\mathrm{CP} 15 \mathrm{~b}$ and middle part of CNE18. The sporadic occurrence of rare specimens of Chiasmolithus grandis in 
L. J. Cotton et al.
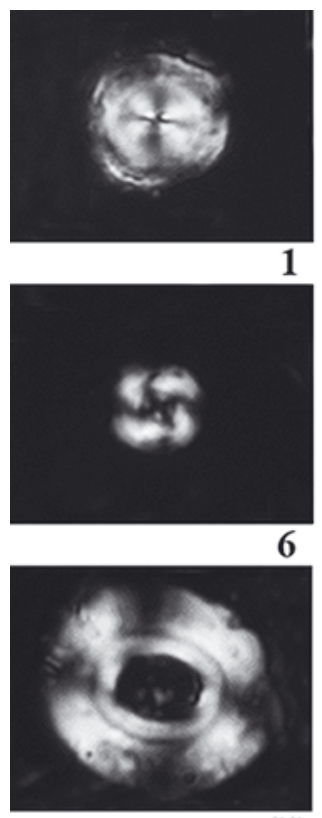

11
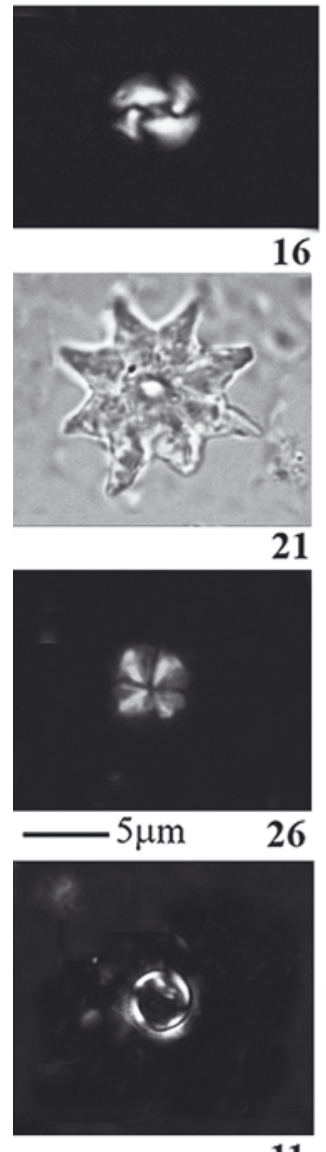

11
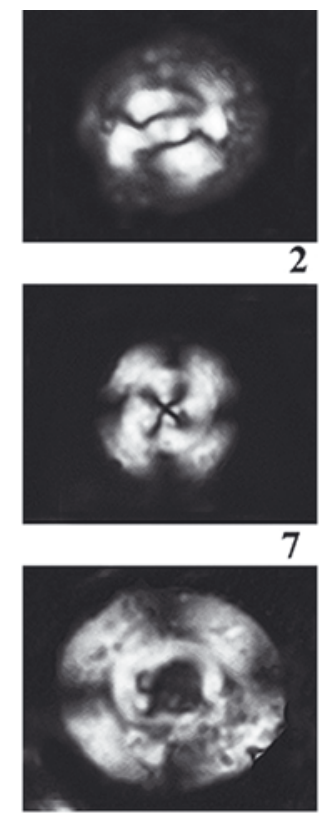

12
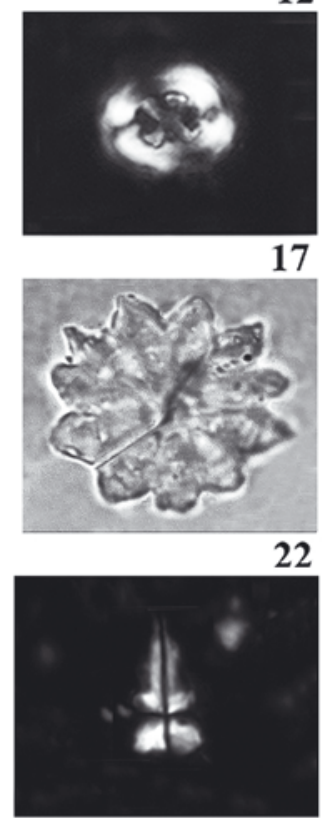

27

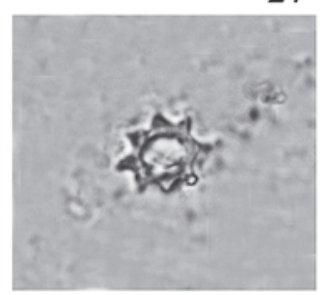

12
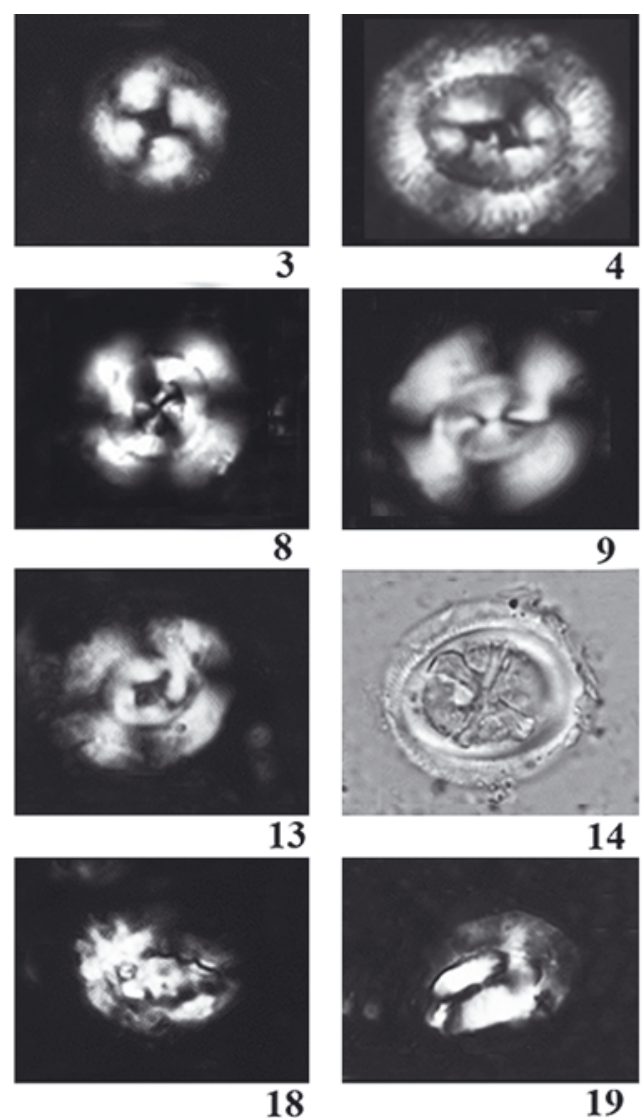

14
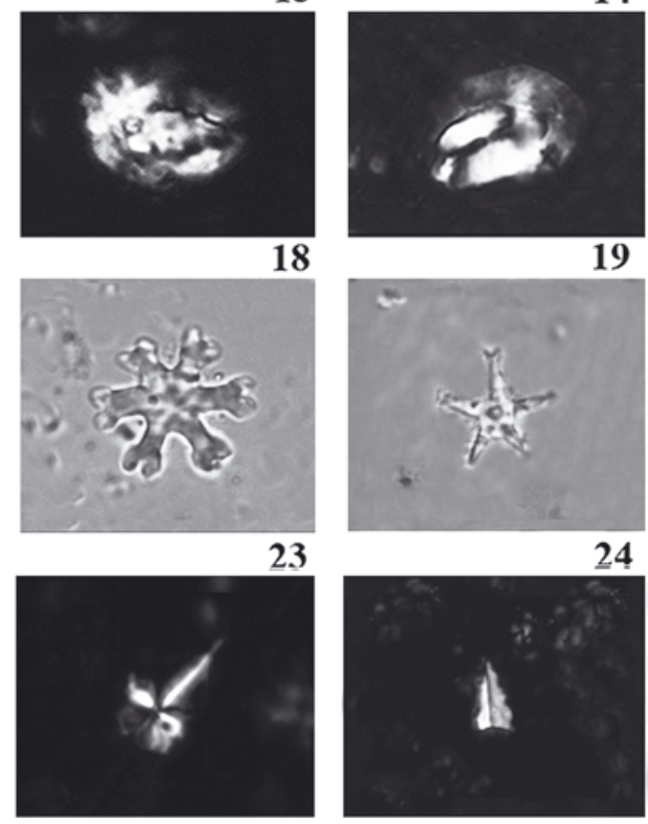

28

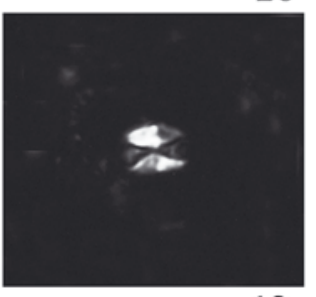

13
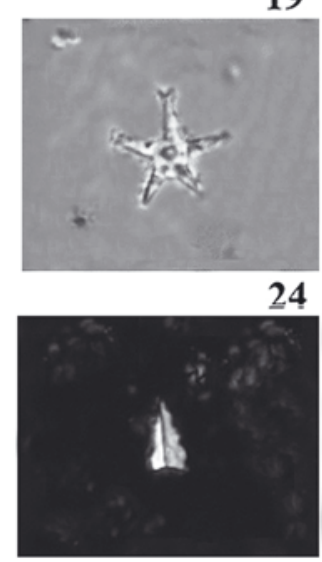

29

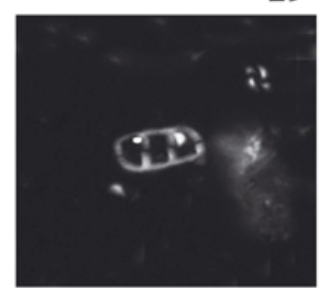

14
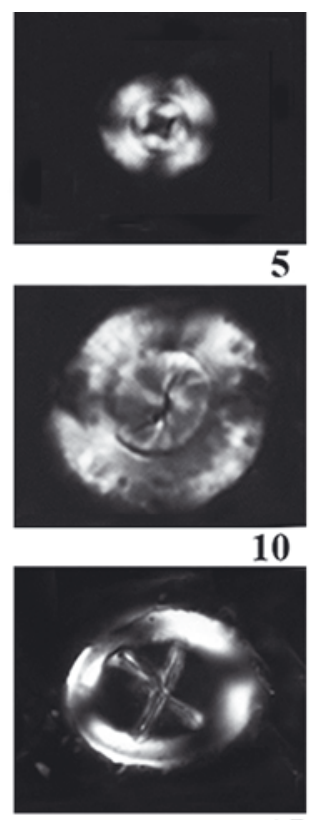

15
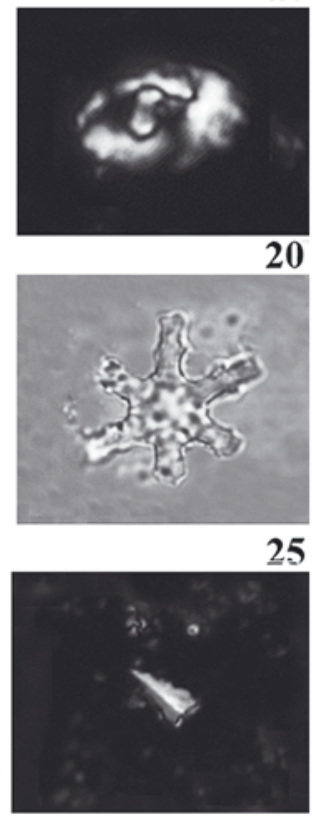

30

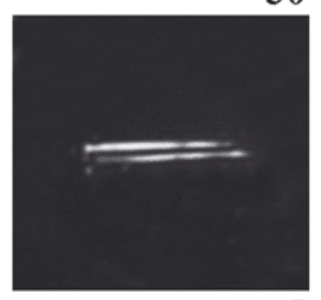

15 
samples V1.13, V1.21, V1.27a-b is considered as reworked. This interpretation is supported by the absence of a clear acme of Cribrocentrum erbae (Fornaciari et al. 2010, Agnini et al. 2014) and the presence of Chiasmolithus oamaruensis from the lowermost levels of the section.

The increase in abundance of C.erbae has been used by Agnini et al. (2014) to define the Base and Top of Zone CNE17. In the Urtsadzor section, C. erbae occurs continuously in the lower samples, being rather common, and displays variations in abundance up section. As there is no interval which can be considered as C. erbae acme, we suggest that the studied section is likely above this level. In the Urtsadzor section, the sporadic occurrence of $C$. oamaruensis has been observed in the lower part of the section up to the level of sample V1.29. Above this level, C.oamaruensis is consistently present. The lowest occurrence of Cribrocentrum isabellae marks the Base of Zone CNE19 according to Agnini et al. (2014). In Urtsadzor section, very rare $C$. isabellae have been recognized in sample V1.18. This species is continuously present in the upper part of the section but in rather low abundances. The most reliable level for the base of Zone CNE19 is identified between samples V1.29 and V1.31.

Our observations on the nannofossil assemblages in the Urtsadzor section show that there are few reliable nannofossil events for zonal subdivision in the studied interval. The presence of Chiasmolithus oamaruensis and Isthmolithus recurvus throughout the section and the occurrence of C.isabellae, marker of the CNE19 Zone, in the middle upper part suggest that the studied section lies well above the base of the Priabonian as traditionally interpreted, with the entire section being Priabonian in age. The occurrence of rare I.recurvus from the base of the section suggests a correlation to the C17n. 1n subchron (Agnini et al. 2011).

\subsection{Larger benthic foraminiferal biostratigraphy}

The standard biostratigraphic scheme for the Western Tethyan region, the Shallow Benthic Zonation, by Serra-Kiel et al. (1998) with modification by Less and Özcan (2012), was used as it is the most applicable of the existing zonal schemes, as until now studies of Armenian Paleogene LBF have not been widely published as international papers (e.g. Krasheninnikov et al. 1985, Zakrevskaya et al. 2014). The LBF assemblages are diverse, and appear typical for the Eocene of the Tethyan region (e.g. Serra Kiel et al. 1998), and relatively consistent throughout the section (Fig. 12). Assemblages are dominated by Nummulites, other nummulitids and orthophragmines. The Nummulites millecaput-group occurs throughout the section, but its abundance decreases within the upper part of the section. The taxa appear in the correct stratigraphic order and all are typical of this age with no reworked older

Fig. 10. Calcareous nannofossils: 1 - Bicolumnus ovatus Wei and Wise, Sample V1.07, cross-polarized light (XPL); 2 Coccolithus biparteoperculatus (Varol) Bown and Dunkley Jones, Sample V1.10, XPL; 3 - Coccolithus formosus (Kamptner) Wise, Sample V1.18, XPL; 4 - Coccolithus pelagicus (Wallich) Schiller, Sample V1.32, XPL; 5 - Cyclicargolithus floridanus (Roth and Hay) Bukry, Sample V1.18; 6 - Cribrocentrum reticulatum (Gartner and Smith) Perch-Nielsen, Sample V1.18, XPL; 7 - Cribrocentrum erbae Fornaciari, Agnini, Catanzariti, Rio, Bolla, Valvasoni, Sample V1.18, XPL; 8 - Cribrocentrum isabellae Fornaciari, Agnini, Catanzariti, Rio, Bolla, Valvasoni, Sample V1.32, XPL; 9-Dictyococcites bisectus (Hay, Mohler and Wade) Roth, Sample V1.18, XPL; 10 - Dictyococcites stavensis Varol, Sample V1.11, XPL; 11 Reticulofenestra umbilicus (Levin) Martini and Ritzkowski, Sample V1.20, XPL; 12 - Reticulofenestra hillae Bukry and Percival, Sample V1.32, XPL; 13 - Dictyococcites filewiczii Wise and Wiegand Sample V1.32, XPL; 14-15 - Chiasmolithus oamaruensis (Deflandre) Hay, Mohler and Wade, Sample V1.32: 14 - transmitted light (IIPL), 15 - XPL; 16 - Reticulofenestra lockeri Müller, Sample V1.08, XPL; 17 - Chasmolithus altus Bukry and Percival, Sample V1.24, XPL; 18 - Helicosphaera reticulata Bramlette and Wilcoxon, Sample V1.08, XPL; 19-Helicosphaera compacta Bramlette and Wilcoxon, Sample V1.23, XPL; 20 - Helicosphaera bramlettei (Müller) Jafar and Martini, Sample V1.07, XPL; 21 - Discoaster saipanensis Bramlette and Riedel, Sample V1.12, IIPL; 22 - Discoaster barbadiensis Tan, Sample V1.04, IIPL; 23 - Discoaster deflandrei Bramlette and Riedel, Sample V1.12A IIPL; 24 - Discoaster tanii Bramlette and Riedel, Sample V1.18, IIPL; 25 - Discoaster nodifer (Bramlette and Riedel) Bukry, Sample V1.12A, IIPL; 26 - Sphenolithus moriformis (Bronnimann and Stradner) Bramlette and Wilcoxon, Sample V1.11, XPL; 27 - Sphenolithus radians Deflandre, Sample 32, XPL; 28 Sphenolithus pseudoradians Bramlette and Wilcoxon, Sample V1.02, XPL; 29-30 - Sphenolithus predistentus Bramlette and Wilcoxon, XPL: 29 - view at $0^{\circ}, 30$ - view at 45 , Sample V1.32, XPL; 31 - Umbilicosphaera bramlettei (Hay and Towe) Bown, Dunkley-Jones and Young, Sample V1.02, XPL; 32 - Corannulus germanicus Stradner, Sample V1.12, XPL; 33 - Lanternites minutus Stradner, Sample V1.02, XPL; 34 - Isthmolithus recurvus Deflandre, Sample V1.32, XPL; 35 Blackites spinosus (Deflandre and Fert) Hay and Towe, Sample V1.17, XPL. 

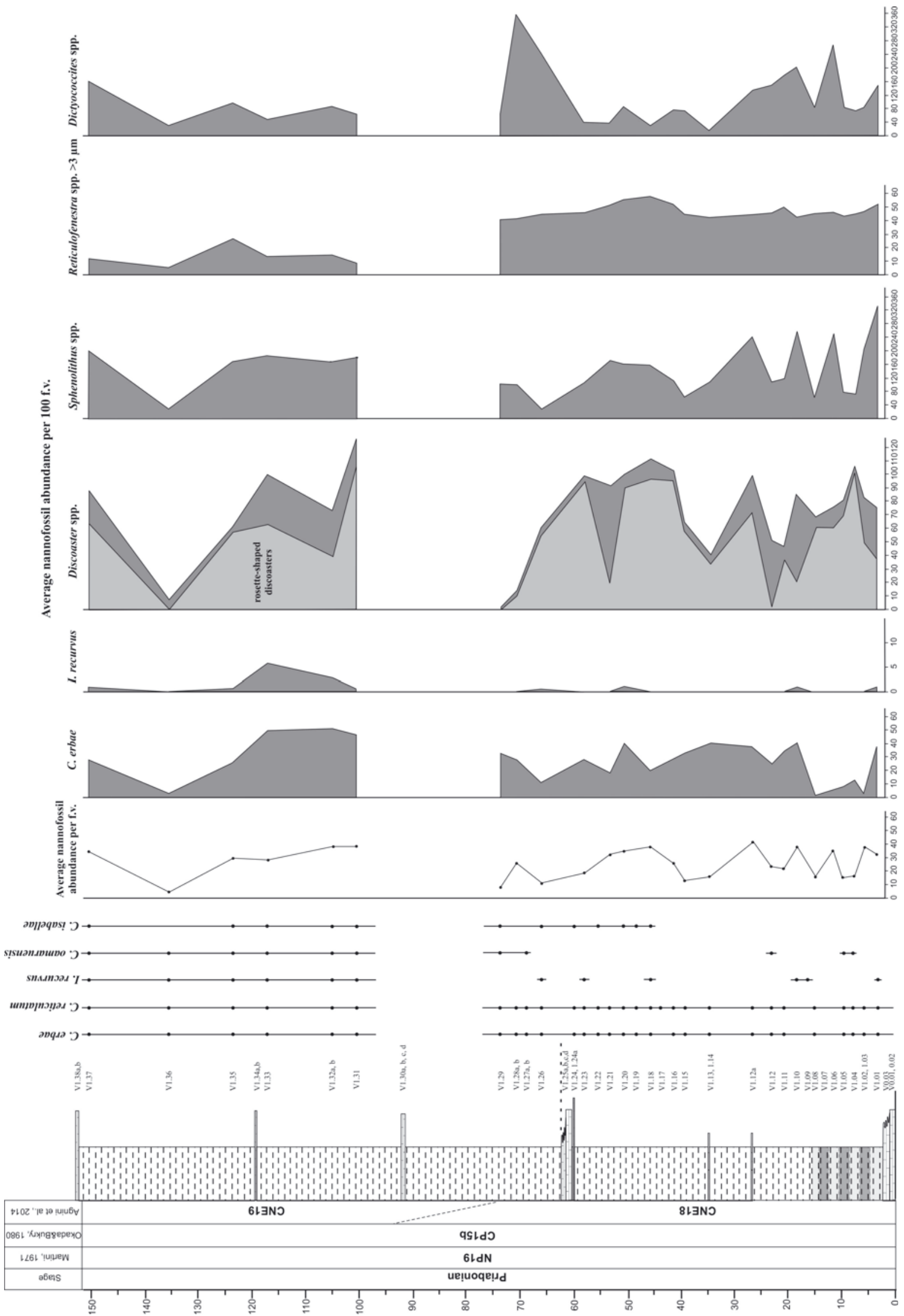
taxa identified, indicating redeposition was likely penecontemporaneous with the siltstones. However, since the limestones are made up by resedimented material, we cannot completely rule out the possibility of heterochronous reworking. Marker and common taxa are shown in Fig. 13.

Nummulites belonging to the N.millecaput-group are one of the most distinctive taxa found in the succession, and are characterised by their large flattened tests, high chambers and thin wavy septa (Schaub 1981). They are present in all limestone beds, but in samples V0.01, V1.24a and V1.25 they are abundant and a dominant component, whilst in samples V1.30, V1.34 and V1.38a they are relatively rare. All specimens are A forms with the exception of sample V1.25, where fragments of large specimens $(8-13 \mathrm{~cm}$ in diameter) were found.

Spiroclypeus is also a distinctive LBF, characterised by having chamberlets and lateral splitting of the spiral wall (see Lunt and Renema 2014). A single lose specimen of Spiroclypeus was found in sample V1.30, but it is otherwise absent until the uppermost limestone bed (V1.38) in which a number of specimens were found and identified as $S$. sirotti. The first occurrence

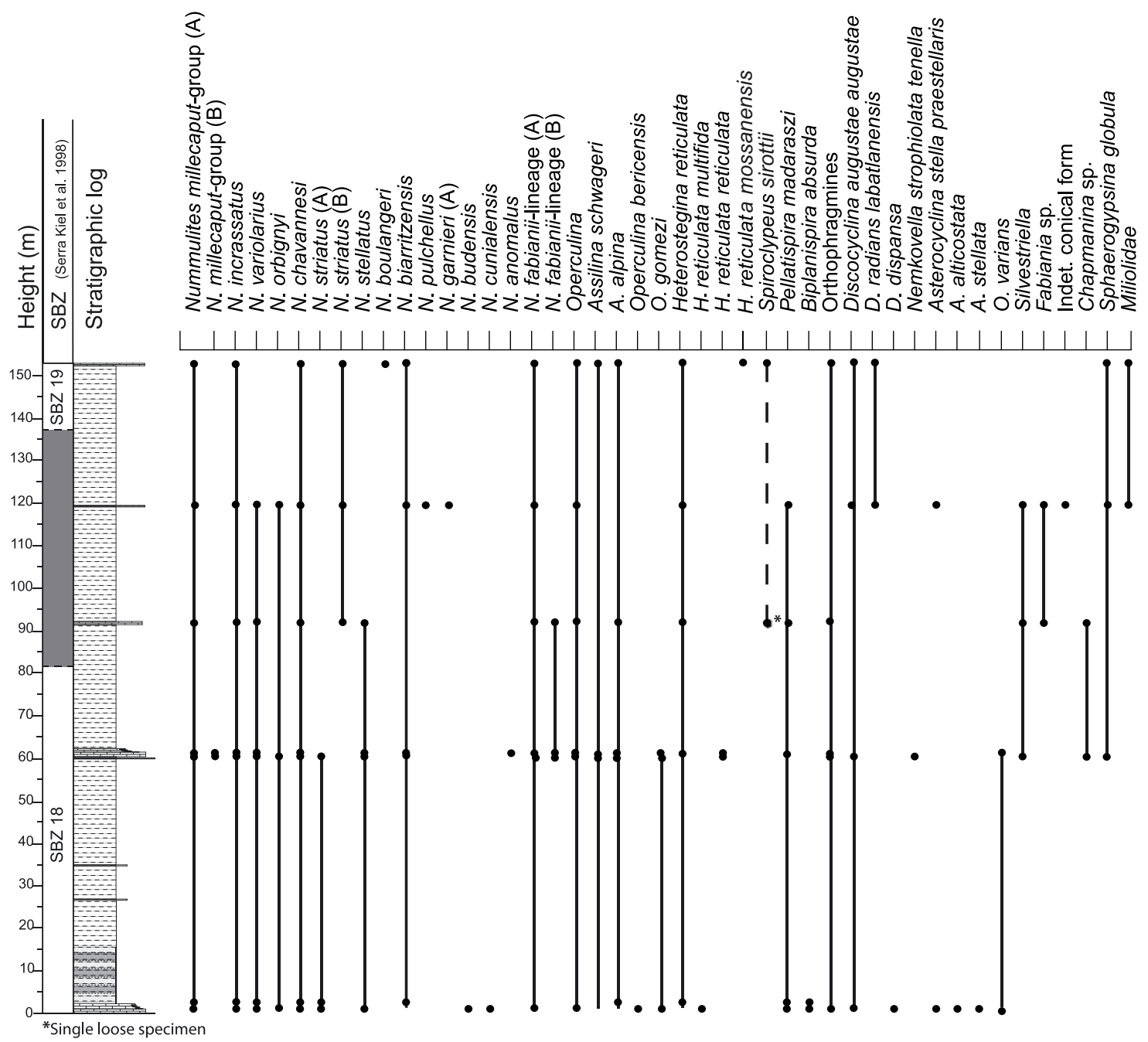

Fig. 12. Stratigraphic range chart of larger benthic foraminifera; lines show interpolations between observed occurrences (dots). Grey area represents zone in which the boundary between SBZ 18 and 19 occurs.

Fig. 11. Stratigraphic range of key nannofossil species in the Urtsadzor section - lines show interpolations between observed occurrences (dots), variation in total nannofossil abundance and relative abundance of some nannofossil taxa. 


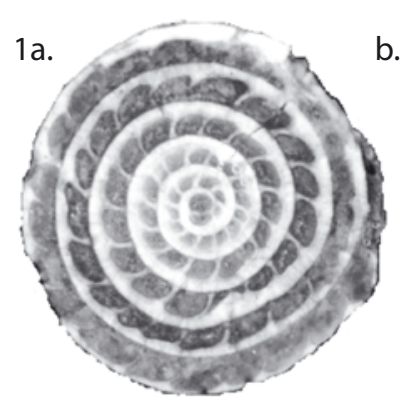

b. 2 a.

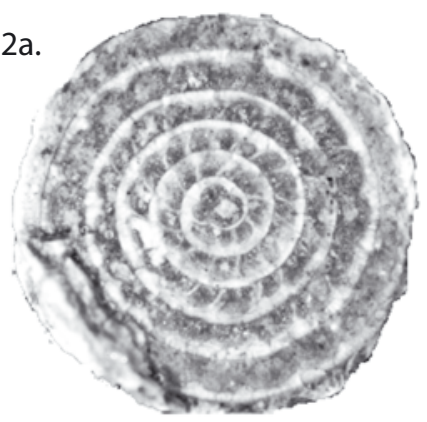

b.

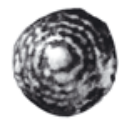

3.
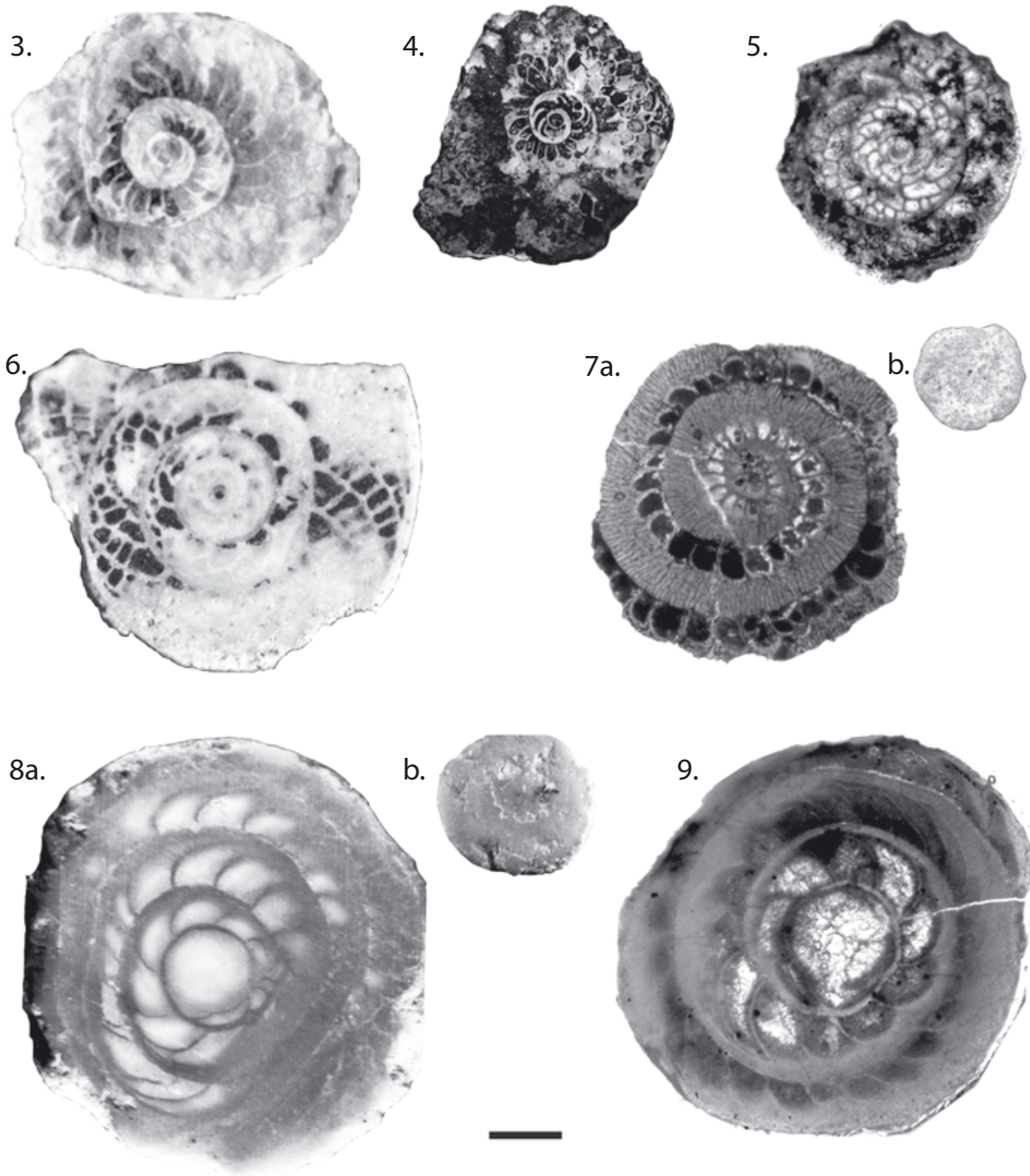

b.
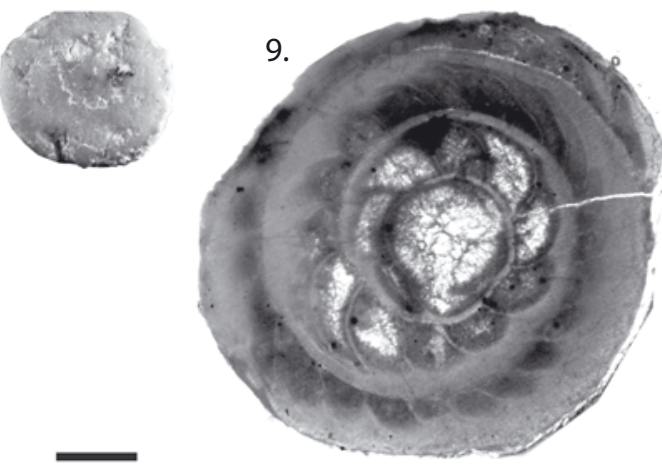

Fig. 13. Biostratigraphically significant larger benthic foraminiferal taxa: $\mathbf{1}-$ Nummulites hormoensis (sample V1.25; a equatorial section; $\mathrm{b}$ - external view); $\mathbf{2}$ - Nummulites fabianii (Prever in Fabiani) (a - equatiorial section; $b$ - external view; sample V1.38); 3 - Heterostegina reticulata Rütimeyer, 1850 multifida (Bieda) (equatorial section; sample V0.01); 4 - Heterostegina reticulata Rütimeyer reticulata (equatorial section; sample V1.30); 5 - Spiroclypeus sirottii Less \& Özcan, (equatorial section; sample V1.38); 6 - Spiroclypeus sirottii (equatorial section; sample V1.30); 7 - Pellatispira madaraszi (Hantken) (equatorial section; sample V0.01); 8 - Nummulites millecaput-group (a - equatorial section; b - external view; sample V1.25); 9 - Nummulites millecaput-group d'Archiac, (equatorial section; sample V1.38). Scale bar represents $0.5 \mathrm{~mm}$ for specimens $1-6$ and $1 \mathrm{~mm}$ for $7-9$. 
of Spiroclypeus indicates the start of SBZ 19 (Serra Kiel et al. 1998, Less and Özcan 2012).

The Base of Nummulites fabianii is an additional widely used indicator of SBZ 19. Members of the Nummulites fabianii-lineage (reticulate nummulites) are frequently used as biostratigraphic indicators, due to their increasing proloculus size with time (e.g. Schaub 1981, Papazzoni 1998, Özcan et al. 2009, Less and Özcan 2012). Reticulate nummulites are widespread around the Bartonian/Priabonian boundary. A number of them, however, belong to the N. ptukhianilineage which is frequently misinterpreted as the N. fabianii-lineage (e.g. Schaub 1981) but they have far larger proloculi than $N$. fabianii-lineage members of the same age. Recently these two lineages are clearly distinguished by Cotton et al. (2015). In the studied section reticulate nummulites are represented only by the commonly occurring N.fabianii-lineage. Both A and B forms are present, though A forms are more abundant. Specimens measured from samples V0.1 to V1.25a have proloculi of around 160 to $170 \mu \mathrm{m}$ in average diameter which assigns them to $N$. hormoensis according to Özcan et al. (2009). Specimens in the upper part of the section have slightly larger proloculi, although they are rare in sample V1.30 and may also fall within the range of $N$. hormoensis or may be intermediate forms between $N$.hormoensis and N.fabianii as defined by Papazzoni (1998) and Özcan et al. (2009). Specimens measured from the uppermost sample, V1.38 have an average proloculus diameter of $242 \mu \mathrm{m}$ indicating they are $N$.fabianii. This therefore indicates the top of the section includes the base of SBZ 19.

Additional biostratigraphic indicators include $\mathrm{Pel}$ latispira and Heterostegina. Pellatispira occurs from limestones V0.01 to V1.34 and is a marker for the Subzone SBZ18B to the end of SBZ20 (Serra Kiel et al. 1998, Less and Özcan 2012), indicating the section is not older than the upper part of SBZ18. Heterostegina reticulata is found within all limestones and is indicative of SBZ18B to SBZ20, further supporting a LBF age of no older than SBZ18B. The number of post embryonic un-subdivided chambers $(\mathrm{X})$ is known to decrease in time and is used to define subspecies and further refine the biostratigraphy (Less et al. 2008). Heterostegina reticulata multifida $\left(\mathrm{X}_{\text {mean }}=8.1\right)$ occurs in sample V0.1 and indicates the base of Subzone SBZ 18C. In samples V1.25 and V1.30 Heterostegina reticulata reticulata $\left(\mathrm{X}_{\text {mean }}=3.9\right.$ and 2.9 respectively $)$ was identified marking the upper part of Subzone SBZ 18C (Less et al. 2008, Less and Özcan 2012). Rare
H.reticulata mossanensis $\left(\mathrm{X}_{\text {mean }}=2.2\right)$ were identified form V1.38 indicating SBZ 19.

The LBF data indicate that the SBZ 18/19 boundary, generally considered to be the Bartonian/Priabonian boundary, is in the upper part of the Urtsadzor section with a lowest possible level of just below V1.30, based on the single occurrence of Spiroclypeus with the uppermost bed V1.38 certainly being within SBZ 19. The remainder of the section likely belongs to SBZ $18 \mathrm{C}$ based on the presence of Pellatispira and subspecies of Heterostegina.

\subsection{Palaeomagnetic stratigraphy}

Thermomagnetic runs of two different lithologies were performed (marl, V0.01 and limestone, V1.27). For sample V0.01, magnetisation is low, and decreases gradually upon heating and shows reversible behaviour up to $\sim 450^{\circ} \mathrm{C}$. Above this temperature, the magnetisation increases slightly upon cooling. This effect is also observed at $\sim 550^{\circ} \mathrm{C}$. The decrease in magnetisation up to about $350-400^{\circ} \mathrm{C}$ can be explained by the breakdown of iron sulphides. The increase in magnetisation from $400^{\circ} \mathrm{C}$ to $500^{\circ} \mathrm{C}$ is caused by oxidation of iron sulphides, most likely pyrite, converting to magnetite between $380-420^{\circ} \mathrm{C}$. Therefore, all samples for thermal demagnetisation were heated up to a maximum temperature of $380^{\circ} \mathrm{C}$. Sample V1.27 does not show this behaviour, but shows a rather gradual decrease in magnetisation over the whole temperature range. Magnetisation is also very low in this sample.

Figure 14 shows Zijderveld diagrams of samples that represent different demagnetisation behaviour and directions. Although intensities of the samples are generally low, 19 out of 45 samples, representing 16 out of 40 levels, gave reliable pre-tilt signals. The remaining samples show partial or total overprint, probably due to weathering. Post-tilt signals are relatively easy to distinguish, due to the steep dip of the beds. Both normal and reversed polarity pre-tilt signals can be distinguished, and only normal polarity post-tilt signals are observed. The declination of post-tilt signals varies considerably (up to around 90 degrees), possibly due to partial overprinting of the pre-tilt signal. The declination and inclination of the pre-tilt signals do not show a perfect agreement to what is expected for the paleolatitude of Urtsadzor during the Eocene. This could be related to either inclination shallowing, or a partial overprint by a post-tilt component. In the magnetostratigraphic column, all directions are plotted (Fig. 15). Samples that carry a post-tilt signal are indi- 

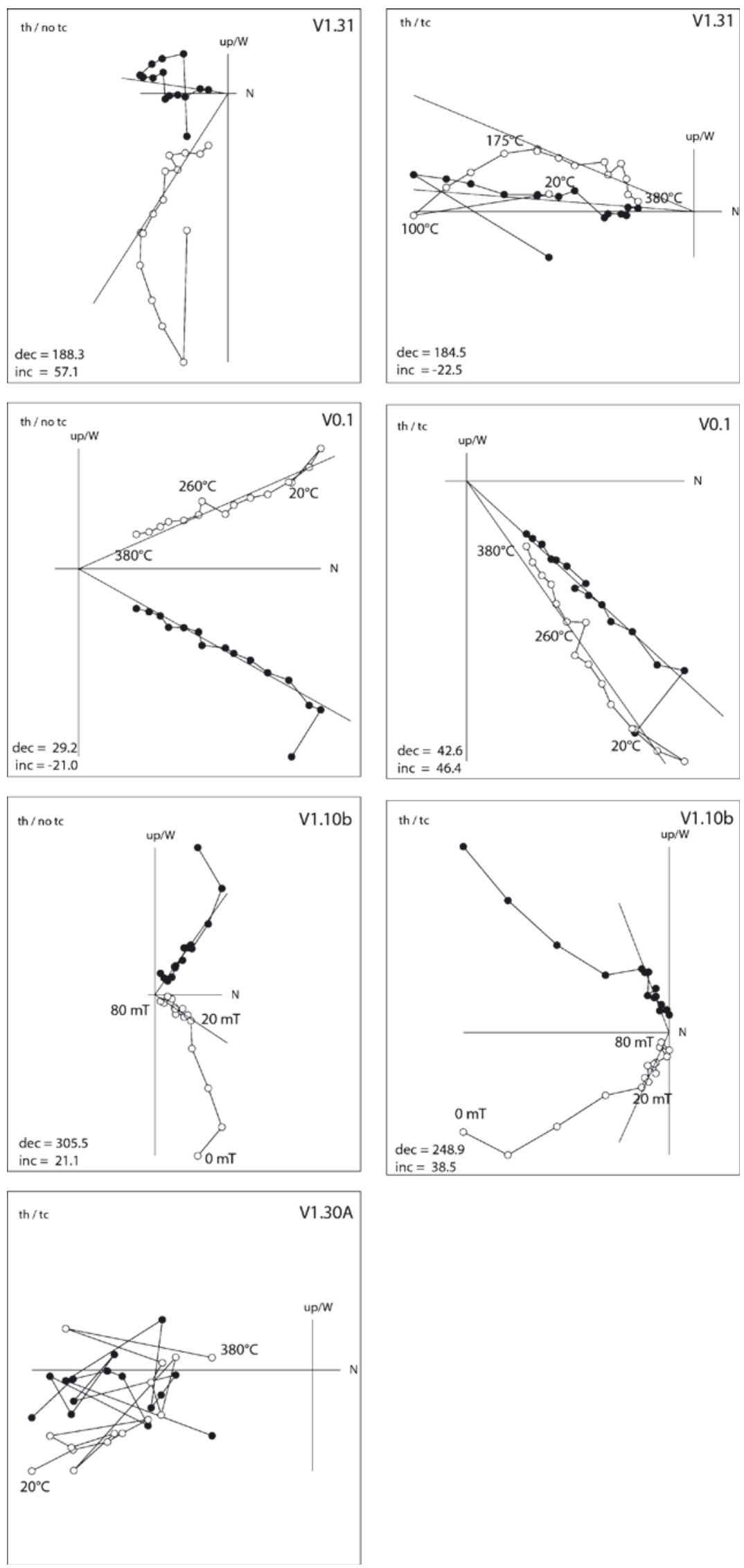

Fig. 14. Interpretation and examples of characteristic remanent magnetization directions (ChRM) (Zijderveld diagrams) of representative samples with (tc) and without (notc) tectonic correction. 


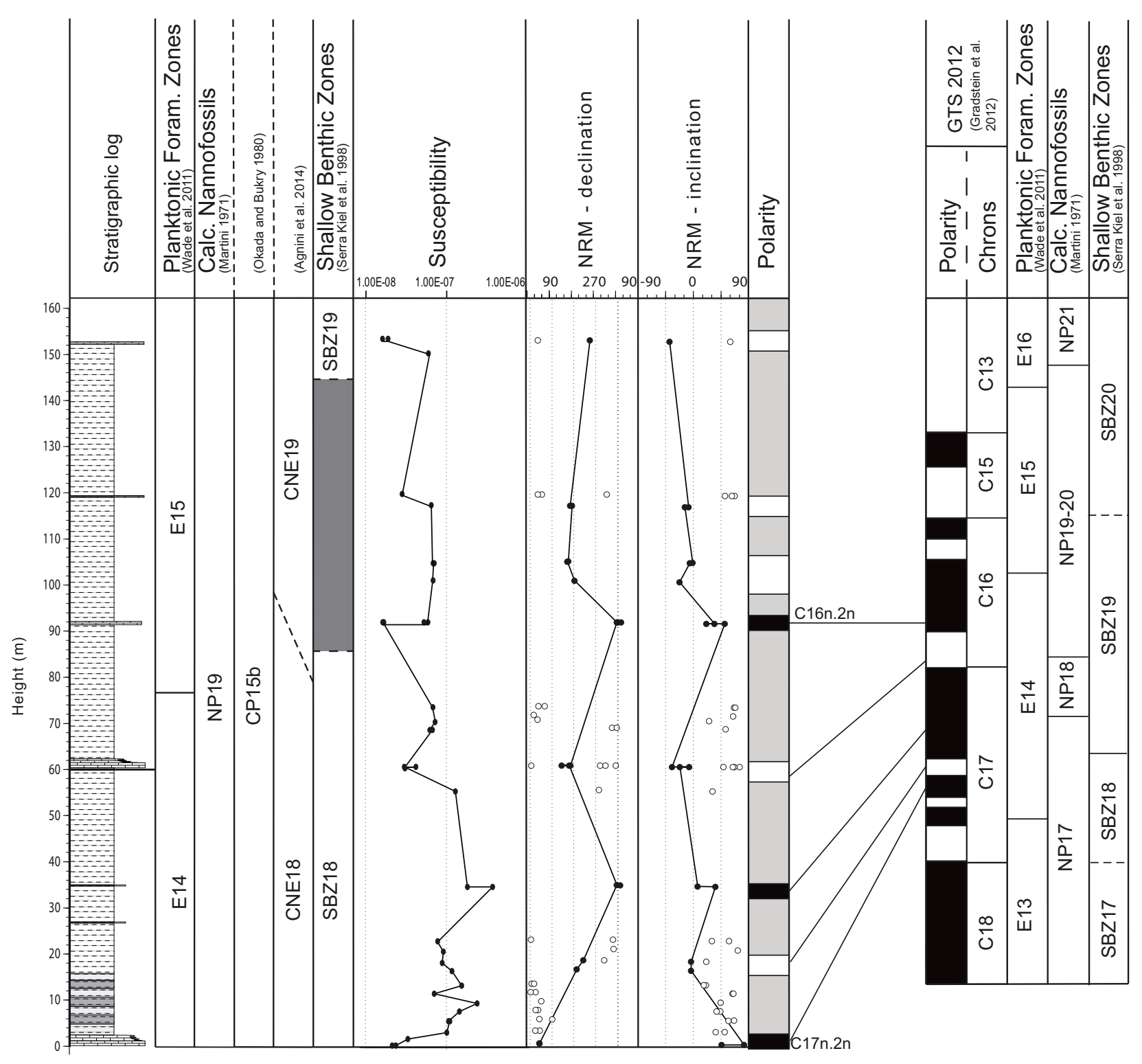

Fig. 15. Summary figure showing biostratigraphy of the Urtsadzor section, studied here, magnetic susceptibility, declination and inclination of the interpreted characteristic remanent magnetization and correlation of magnetic chrons to the GTS 2012.

cated with open dots and samples that carry a pre-tilt signal are indicated by the closed dots. A total of six polarity intervals can be distinguished from the section. A characteristic polarity pattern cannot be determined, due to the low resolution and the large number of post-tilt signals, and comparison to the biostratigraphic record is needed for correlation to the Geomagnetic Polarity Time Scale (Gradstein et al. 2012; Fig. 15).

\section{Discussion}

The planktonic foraminiferal and nannofossil biostratigraphic determinations are in good agreement with each other, and show that the section is well above the base of the Priabonian as traditionally viewed in both zonal schemes. In planktonic foraminiferal zonations the Urtsadzor succession studied here falls within Zones E14 and E15 and calcareous nannofossil Zones CNE18 and CNE 19. This allows an interpretation of the limited magnetostratigraphic polarity information (Fig. 15). The continuous occurrence of $C$. isabellae is 
from sample V1.29 upwards, where the boundary between CNE18/19 has been approximately identified. This new bioevent has been calibrated to subchron C16n. 2n (Fornaciari et al. 2010, Agnini et al .2014) and roughly corresponds to the common occurrence of $I$. recurvus calibrated to C16n. $2 \mathrm{n}$ in Fornaciari et al. (2010; Massignano section) and Fioroni et al. (2012). A further constraint is provided by the Top of Globigerinatheka semiinvoluta which occurs about $18 \mathrm{~m}$ below a normal polarity sample, which is consistent with the event being in subchron C16n. 2n (Wade et al. 2011).

The LBF SBZ 18/19 boundary, traditionally thought to represent the base of the Priabonian, occurs in the upper part of the section. This is unlikely due to reworking as although the limestone beds likely include gravity flows, all identified species are consistent with an upper Eocene age and no older Paleogene species were found. Additionally the LBF, particularly the decrease in abundance and possible disappearance of the $N$. millecaput-group, the first occurrence of Spiroclypeus, the increase in proloculus size within the Nummulites-fabianii lineage and the succession of subspecies of Heterostegina reticulata occur within the expected stratigraphic order, which would be unlikely if significant reworking had occurred. This therefore indicates that the major events at the SBZ 18/19 boundary formerly correlated with the Bartonian/Priabonian boundary (Papazzoni and Sirotti 1995, Serra-Kiel et al. 1998) occur much higher than the major events in the planktonic foraminiferal and other open marine fossil records. Thus, the SBZ 18/19 boundary does not correspond to the base of the Priabonian according to either of the proposed levels at Alano, but occurs much higher within planktonic foraminifera Zone E15 and calcareous nannofossil Zone CNE 19. The exact location of the Bartonian/Priabonian boundary in LBF stratigraphy (probably at the close vicinity of the SBZ 18A/B boundary sensu Less et al. (2008) and Less and Özcan (2012) is still to be elaborated. This is not the first time a higher level has been suggested for the SBZ 18/19 boundary. Costa et al. (2013) carried out integrated LBF and nannofossil biostratigraphy within the Igualada region in north-east Spain. Their results showed that SBZ 18 traditionally viewed as belonging entirely to the Bartonian, extended into the early Priabonian correlating with the Zones NP19 and NP20 of Martini et al. (1971), and alongside the first common occurrence of I. recurvus which can be correlated to the Priabonian of both the Alano section and ODP Site 1052 (Fornaciari et al. 2010, Agnini et al. 2011). Papazzoni et al. (2014) found the same correlation in the
Varignano section in northern Italy, with the events of extinction of morozovellids and large acarininids and the Cribrocentrum erbae Acme beginning all occurring above the appearance of Pellatispira, therefore within SBZ 18. It is therefore possible that the LBF events took place at a higher level than previously interpreted and that previous attempts at correlations were hampered by a lack of independent dating. However, it is equally possible that these differences may be due to diachroneity in the LBF extinction levels; Less and Özcan (2012) suggested an "eastward younging trend" to the large Nummulites extinction based on comparisons with the developmental degree of $\mathrm{He}$ terostegina reticulata. Diachroneity could potentially account for the variation in regional correlations, however, thorough integrated stratigraphic studies need to be carried out on more sections within the Tethys and elsewhere to be able to determine the nature of this event.

\subsection{Comparison to Alano di Piave section}

Although the base of the Priabonian stage has yet to be determined it is likely to be placed at one of the proposed levels within the Alano di Piave section in Italy. If the boundary is placed at the Top of Morozovelloides crassatus (Wade et al. 2011) then the entire Urtsadzor section lies within the Priabonian. If it is placed at the locally distinctive "Tiziano bed" within the lower part of Subchron C17n.2n (Agnini et al. 2011) then the correlation is less certain, as it depends on successful identification of the reversal sequence. It is possible that this level correlates with the very base of the Urtsadzor section, but more likely somewhere below it. The LBF SBZ 18/19 boundary as determined from the Urtsadzor section is therefore well above any of the proposed markers. Although our section is above both the 'Tiziano bed' and the muricate planktonic foraminiferal extinction level it shows the importance of selecting a GSSP which can be utilized outside of the Tethyan region and the need for improved correlation of the LBF record for the GSSP to have relevance in shallow marine environment.

\section{Conclusion}

Integrated stratigraphy has shown that the Urtsadzor section as sampled in this study is entirely within the Priabonian according to either of the proposed GSSP criteria, that is within planktonic foraminiferal Zones 
E14 and E15 and calcareous nannoplankton Zones CNE 18 and CNE 19. The base of the section correlates to subchron $\mathrm{C} 17 \mathrm{n} .2 \mathrm{n}$ and the sample at V1.30 can be correlated to C16n.2n (Fig. 15). The SBZ 18/19 boundary traditionally thought of as the Bartonian/ Priabonian boundary in the shallow marine water realm occurs within the upper part of the section. It is marked by a decrease in specimens of the Nummulitesmillecaput group and the Base of Spiroclypeus, alongside increasing proloculus size of the reticulate Nummulites fabianii-lineage and a decrease in undivided chambers in successive Heterostegina reticulata subspecies. This finding is in agreement with other recent integrated stratigraphic studies (e.g. Costa et al. 2013, Papazzoni et al. 2014), suggesting that previous correlations are not correct, or that the extinction of the large Nummulites is diachronous between regions. More independent correlations to chronostratigraphy are needed to determine geographical variations in the timing of this event. This work therefore has significance for the correlation between LBF stratigraphy and global stratigraphic schemes, creating a new calibration point with the geological timescale (Gradstein, 2012; see Fig. 15).

Acknowledgements. L. Cotton and W.Renema were supported by Netherlands Organization for Scientific Research (NWO) grant number ALW 82201 009. The work of E.Zakrevskaya and E. Shcherbinina was financially supported by RFBR Project no. 15-55-05102 and represents a part of the research on the State Programs no.0135-2014-0070. The work of F. Hayrapetyan was supported by Project no. 15RF-078. The travel of G. Less to Armenia was supported by OTKA (Hungarian Scientific Research Fund) Project No.100538. P.N.Pearson was supported by NERC Grant NE/I005870/1. S. Monechi was supported by MIUR/PRIN grant 2010X3PP8J_005. C. A. Papazzoni was funded by the Italian Ministry of Education and Research (MIUR) funds PRIN 2010-2011 project "Past Excess $\mathrm{CO}_{2}$ worlds: biota responses to extreme warmth and ocean acidification". B. Wade was supported by UK Natural Environment Research Council (NERC) reference number NE/G014817. A. van der Boon and W.Krijgsman were supported by the Netherlands Geosciences Foundation (ALW) with support from the Netherlands Organization for Scientific Research (NWO). Jim Davy and Emily Walsh assisted with planktonic foraminifera sample preparation, funded through UCL and a Marie Curie Career Integration Grant "ERAS" to B. Wade. We would like to thank Claudia Agnini and Eliana Fornaciari for exchange of ideas and fruitful suggestions. The field excursion in 2014 was additionally financially supported by Chairman of the party "Just Russia", S. Mironov, and the International Paleogene Subcommission.

\section{References}

Aghamalyan, V. A., Sargsyan, H.H., Lorsabyan, T. K., Israelyan, A.G., 2012. Main tectonic units of Armenia. Proceedings of Yerevan State University. Geology and Geography 1, 3-12.

Agnini, C., Fornaciari, E., Giusberti, L., Grandesso, P., Lanci, L., Luciani, V., Muttoni, G., Pälike, H., Rio, D., Spofforth, D. J. A., Stefani, C., 2011. Integrated biomagnetostratigraphy of the Alano section (NE Italy): A proposal for defining the middle-late Eocene boundary. Geological Society of America Bulletin 123, 841-872.

Agnini, C., Fornaciari, E., Raffi, I., Catanzariti, R., Pälike, H., Backman, J., Rio, D., 2014. Biozonation and biochronology of Paleogene calcareous nannofossils from low and middle latitudes. Newsletters on Stratigraphy 47, $131-181$.

Aubry, M.-P., 1992. Late Paleogene nannoplankton evolution: A tale of climatic deterioration. In: Prothero, D.R. and Berggren, W.A. (Eds.), Eocene-Oligocene Climatic and Biotic Evolution. Princeton Univ. Press, Princeton, N. J., pp. 272-309.

Avanesyan, M. A., 2004. Geologic-structural features of Yerevan-Vedi graben-synclinorium. PhD dissertation. Yerevan, $158 \mathrm{p}$.

Avetisyan, V.A., Azaryan, N. R., Hakobyan, V.T., Hasratyan, V.P., Aslanyan, P.M., Satian, M.A., Tashyan, A. A., Arakelyan, R.A., Abovyan, S.B., Karapetyan, K.I., Mnatsakanian, A.K., Nisanyan, G.B., Petrosov, I.Kh., Martirosyan, Y.A., Grigoryan, S.M., 1964. Geological structure of the upstream basin of Vedi river. Technical report, IGS of NAS of Armenian SSR, 615 p (in Russian).

Bassi, D., Cosovic, V., Papazzoni, C.A., Ungaro, S., 2000. The Colli Berici. In: Bassi, D. (Ed.), Field-trip guidebook: Shallow water benthic communities at the MiddleUpper Eocene boundary. Southern and North-Eastern Italy; Slovenia; Croatia; Hungary. Fifth Meeting of the IUGS-UNESCO IGCP 393. July $18^{\text {th }}-31^{\text {st }}$. Annali Universitá di Ferrara 8, 43-57.

Berggren, W.A., Pearson, P.N., 2005. A revised tropical to subtropical planktonic foraminiferal zonation of the Eocene and Oligocene. Journal of Foraminiferal Research 35, 279-298.

Berggren, W.A., Pearson, P.N., Huber, B.T., Wade, B.S., 2006. Taxonomy, Biostratigraphy and Phylogeny of Eocene Acarinina. In: Pearson, P.N., Olsson, R. K., Huber, B. T., Hemleben, C., Berggren, W. A. (Eds.), Atlas of Eocene Planktonic Foraminifera. Cushman Foundation Special Publication 41, 257-326.

Blow, W.H., 1969. Late Middle Eocene to Recent planktonic foraminiferal biostratigraphy. In: Brönnimann, P., Renz, H.H. (Eds.), Proceedings of the First International Conference on Planktonic Microfossils, Leiden, E.J. Brill 1, p. 199-422.

Bown, P. R., Young, J. R., 1998. Techniques. In: Bown, P. R. (Ed.), Calcareous Nannofossil Biostratigraphy. Kluwer Academic Publishing, Dordrecht, p. 16-28. 
Bralower, T. J., 2002. Evidence of surfacewater oligotrophy during the Paleocene-Eocene thermal maximum: nannofossil assemblage data from Ocean Drilling Program Site 690, Maud Rise, Weddel Sea. Paleoceanography 17 (2), 1029-1042. doi:10.1029/2001PA000662.

Bukry, D., 1973. Low-latitude coccolith biostratigraphic zonation. Initial Rep. Deep Sea Drill. Proj. 15, 685-703.

Bukry D., 1981. Cenozoic coccoliths from the Deep Sea Drilling Project. SEPM Special Publication 32, 335-353.

Cande, S.C., Kent, D. V., 1995. Revised calibration of the geomagnetic polarity timescale for the Late Cretaceous and the Cenozoic. Journal of Geophysical Research 100, 6093-6095.

Coccioni, R., 1988. The genera Hantkenina and Cribohantkenina (foraminifera) in the Massignano section (Ancona, Italy). In: Premoli Silva, I., Coccioni, R., Montanari, A. (Eds.), The Eocene-Oligocene boundary in the Marche-Umbria Basin (Italy). International Subcommission on Paleogene Stratigraphy, Eocene-Oligocene Meeting, Ancona, Special publication 2, p. 81-96.

Costa, E., Garcés, M., López-Blanco, M., Serra-Kiel, J., Bernaola, G., Cabrera, L., Beamud, E., 2013. The Bartonian-Priabonian marine record of the eastern South Pyrenean foreland basin (NE Spain): a new calibration of the larger foraminifers and calcareous nannofossil biozonation. Geologica Acta 11, 177-193.

Cotton, L. J., Pearson, P.N., Renema, W., 2015. A place for Nummulites ptukhiani? A new lineage of reticulate Nummulites from Kilwa District, Tanzania. Journal of Systematic Palaeontology, http://dx.doi.org/10.1080/147720 19.2015.1079562.

Da Silva, A.-C., Dekkers, M.J., Mabille, C., Boulvain, F., 2012. Magnetic susceptibility and its relationship with paleoenvironments, diagenesis and remagnetization: examples from the Devonian carbonates of Belgium. Studea Geophysica et Geodaetica 56, 677-704.

Edwards, A.R., 1968. The calcareous nannoplankton for Tertiary New Zealand climates. Tuatara 16, 26-31.

Ellwood, B., Crick, C., El Hassani, A., Benoist, S., Young, R., 2000. Magnetosusceptibility event and cyclostratigraphy method applied to marine rocks: detrital input versus carbonate productivity. Geology 28, 1135-1138.

Fioroni, C., Villa, G., Persico, D., Wise, S. W., Jr., Pea, L., 2012. Revised middle Eocene -upper Oligocene calcareous nannofossil biozonation for the Southern Ocean. Revue de Micropaleontologie 55, 53-70.

Fisher, R., 1953. Dispersion on a Sphere. Proceedings of the Royal Society, A 217, 295-305.

Fornaciari, E., Agnini, C., Catanzariti, R., Rio, D., Bolla E.M., Valvasoni, E., 2010. Mid-latitude calcareous nannofossil biostratigraphy, biochronology and evolution across the middle to late Eocene transition. Stratigraphy 7, 229-264.

Gabrielyan, A.A., 1955. Division scheme of Paleogene of Armenia. DAS USSR 105, No 4, 790-793.

Gabrielyan, A.A., 1957. Seven nummulites horizons in Paleogene deposits of Armenia. DAS ASSR 25, No 3, 149-154.
Gabrielyan, A.A., 1964. Paleogene and Neogene of Armenian SSR. Akademiya Nauk Armyanskoi SSR, Yerevan, p. 299 pp. (In Russian).

Gradstein, F., Ogg, J., Smith, A., 2012. A Geologic Timescale. Cambridge University Press, Cambridge, p. 1176.

Grigoryan, S.M., 1964. Paleogene and Neogene of Armenian SSR. Akademiya Nauk Armyanskoi SSR, Yerevan, 299 pp.

Grigoryan, S.M., 1979. Nummulitids of the upper Eocene and Oligocene deposits of south-western part of Armenian SSR. Akademiya Nauk Armyanskoi SSR, Yerevan, $100 \mathrm{pp}$.

Grigoryan S.M., 1986. Nummulitids and Orbitoids of Armenian SSR. Academiya Nauk Armyanskoi SSR, Yerevan, $216 \mathrm{pp}$.

Hallock. P., Premoli Silva, I., Boersma, A., 1991. Similarities between planktonic and larger foraminiferal evolutionary trends through Paleogene paleoceanographic changes. Palaeogeography, Palaeoclimatology, Palaeoecology 83, 49-64.

Hay, W.W., 1996. Tectonics and climate. Geologische Rundschau 85, 409-437.

Hay, W.W., 1998. Detrital sediment fluxes from continents to oceans. Chemical Geology 145, 287-323.

Hayrapetyan, F. A., Zakrevskaya, E. Y., 2013. The Paleogene stratigraphic scale of Armenia. In: Fedonkin, M.A. (Ed.), General Stratigraphic Scale of Russia: current state and ways of perfection. All-Russian meeting. May 2325, 2013, Geological Institute RAS, Moscow, p. 324-328 (in Russian with English title).

Hottinger, L., Romero, J., Caus, E., 2001. Architecture and revision of the Pellatispirines, planispiral canaliferous foraminifera from the late Eocene Tethys. Micropaleonto$\log y 47,35-77$.

Kamikuri, S., Wade, B.S., 2012. Radiolarian magnetobiochronology and faunal turnover across the middle/late Eocene boundary at Ocean Drilling Program Site 1052 in the western North Atlantic Ocean. Marine Micropaleontology 88-89, 41-53.

Kirschvink, J.L., 1980. The least-squares line and plane and the analysis of palaeomagnetic data. Geophysical Journal International 62, 699-718.

Koymans, M.R., Langereis, C.G., Pastor-Galan, D., van Hinsbergen, D. J. J., 2016. Paleomagnetism.org: an online multi-platform open source environment for paleomagnetic data analysis. Computers and Geosciences 93, 127137.

Krasheninnikov, B.A., 1973. The ratio of zonal scales on planktonic foraminifera and nannoplankton in the sections of the North Caucasus. Questions of micropaleontology 17, 212-224.

Krasheninnikov, V.A. and Ptukhian, A.E., 1986. Stratigraphic subdivision of Paleogene deposits of Armenia by planktonic microfossils and nummulites. (Regional stratigraphy, zonal scales by planktonic and benthonic microfossils and their correlation). Voprosy micropaleontologii, Moscow, 28, 60-98.

Krasheninnikov, B.A., Ptukhian, A.E., 1973. The ratio of faunas of planktonic foraminifera and Nummulites in the 
Paleogene deposits of Armenia. Voprosy micropaleonto$\operatorname{logii}$ 1, 146-182.

Krasheninnikov, V.A., Muzylöv, N.G., Ptukhian, A.E., 1985. Stratigraphic subdivision of Paleogene deposits of Armenia by planktonic foraminifers, nannoplankton and Nummulites. (Pt I. Reference Paleogene sections of Armenia). Voprosy micropaleontologii 27, 130-169.

Less, G., 1987. Paleontology and Stratigraphy of the European Orthophragminae. Geologica Hungarica series Paleontologica 51, 1-373.

Less, G., Özcan, E., 2008. The late Eocene evolution of nummulitid foraminifer Spiroclypeus in the Western Tethys. Acta Palaeontologica Polonica 53, 303-316.

Less, G., Özcan, E., 2012. Bartonian-Priabonian larger benthic foraminiferal events in the Western Tethys. Austrian Journal of Earth Sciences 105, 129-140.

Less, G., Özcan, E., Papazzoni, C. A., Stockar, R., 2008. The middle to late Eocene evolution of nummulitid foraminifer Heterostegina in the Western Tethys. Acta Palaeontologica Polonica 53, 317-350.

Luciani, V., Giusberti, L., Agnini, C., Fornaciari, E., Rio, D., Spofforth, D. J.A., Pälike, H., 2010. Ecological and evolutionary response of Tethyan planktonic foraminifera to the middle Eocene climatic optimum (MECO) from the Alano section (NE Italy). Palaeogeography, Palaeoclimatology, Palaeoecology 292, 82-95.

Lunt, P., Renema, R., 2014. On the Heterostegina - Tansinhokella - Spiroclypeus lineage(s) in SE Asia. Berita Sedimentologi 30, 6-31.

Marino, M., Flores, J. A., 2002. Middle Eocene to Early Oligocene calcareous nannofossil stratigraphy at Leg 177 Site 1090. Marine Micropaleontology 45, 383-398.

Martini, E., 1971. Standard Tertiary and Quaternary calcareous nannoplankton zonation. In: Farinacci, A. (Ed.), Proceedings of the 2nd Planktonic Conference on Planktonic Microfossils Roma. Tecnoscienza, Roma 2, 739-785.

Monechi, S., Buccianti, A., Gardin, S., 2000. Biotic signals from nannoflora across the iridium anomaly in the upper Eocene of the Massignano section; evidence from statistical analysis. Marine Micropaleontology 39, 219-237.

Mullender, T. A. T., Velzen, A. J., Dekkers, M. J., 1993. Continuous drift correction and separate identification of ferrimagnetic and paramagnetic contributions in thermomagnetic runs. Geophysical Journal International 114, 663-672.

Munier-Chalmas, E., de Lapparent, A., 1893. Note sur la nomenclature des terrains sédimentaires: Bulletin de la Société Géologique de France 21, 438-488.

Newsam, C., Bown, P.R., Wade, B.S., 2015. Muted calcareous nannoplankton response at the Middle/Late Eocene Turnover event in the western North Atlantic. Newsletters on Stratigraphy (submitted).

Okada, H., Bukry, D., 1980. Supplementary modification and introduction of code numbers to the low-latitude coccolith biostratigraphic zonation (Bukry, 1973; 1975). Marine Micropaleontology 5, 321-325.

Olsson, R. K., Hemleben, C., 2006. Taxonomy, biostratigraphy, and phylogeny of Eocene Globanomalina, Planoglo- banomalina n. gen and Pseudohastigerina. In: Pearson, P.N., Olsson, R.K.,Huber, B.T.,Hemleben,C., Berggren, W. A. (Eds.), Atlas of Eocene Planktonic Foraminifera. Cushman Foundation Special Publication 41, 257-326.

Özcan, E., Less, G., Báldi-Beke, M., Kollányi, K., Acar, F., 2009. Oligo-Miocene foraminiferal record (Miogypsinidae, Lepidocyclinidae and Nummulitidae) from the Western Taurides (SW Turkey): Biometry and implications for the regional geology. Journal of Asian Earth Sciences 34, 740-760.

Papazzoni, C.A., 1998. Biometric analyses of Nummulites "ptukhiani" Z.D.Kacharava, 1969 and Nummulites fabianii (Prever in Fabiani, 1905). Journal of Foraminiferal Research 28, 161-176.

Papazzoni, C.A., Sirotti, A.C., 1995. Nummulite biostratigraphy at the Middle/Upper Eocene boundary in the Northern Mediterranean area. Rivista Italiana di Paleontologia e Stratigrafia 101, 63-80.

Papazzoni, C. A., Moretti, A., Luciani, V., Fornaciari, E., Giusberti, L., 2014. Correlation between shallow benthic zones and calcareous plankton zones at the BartonianPriabonian transition: preliminary results from the Varignano section (Trento Province, northern Italy). In: Rocha, R., Pais, J., Kullberg, J. C., Finney S. (Eds.), STRATI 2013 First International Congress on Stratigraphy - At the Cutting Edge of Stratigraphy. Springer, p. 127-130.

Pearson, P.N., Olsson, R.K., Huber, B. T., Hemleben, C., Berggren, W.A. (Eds.), 2006. Atlas of Eocene Planktonic Foraminifera. Cushman Foundation Special Publication 41, 513 pp.

Pearson, P.N., Wade, B.S., 2015. Systematic taxonomy of exceptionally well-preserved planktonic foraminifera from the Eocene/Oligocene boundary of Tanzania. Cushman Foundation Special Publication 45, 85.

Perch-Nielsen, K., 1985. Mesozoic and Cenozoic calcareous nannofossils. In: Bolli, H.M., Saunders, J.B., PerchNielsen, K. (Eds.), Plankton Stratigraphy. Cambridge University Press, Cambridge, p. 329-554.

Premoli Silva, I., Wade, B.S., Pearson, P. N., 2006. Taxonomy of Globigerinatheka and Orbulinoides. In: Pearson, P.N., Olsson, R.K., Huber, B.T., Hemleben, C., Berggren, W. A. (Eds.), Atlas of Eocene Planktonic Foraminifera, Cushman Foundation Special Publication 41, 169212.

Ptukhian, A.E., 1979. Distribution nummulites in Paleogene sediments of Yerevan-Ordubad structural facies zone. Izv. of AS ASSR, Earth Sciences 32, No. 3.

Schaub, H., 1981. Nummulites et Assilines de la Téthys Paléogène. Taxonomie, phylogenèse et biostratigraphie. Schweizerische Paläontologische Abhandlungen 104106, 1-236.

Serra-Kiel, J., Hottinger, L., Caus, E., Drobne, K., Ferrandez, C., Jauhri, A. K., Less, G., Pavlovec, R., Pignatti, J., Samso, J.M., Schaub, H., Sirel, E., Strougo, A., Tambareau, Y., Tosquella, J., Zakrevskaya, E., 1998. Larger foraminiferal biostratigraphy of the Tethyan Paleocene and Eocene. Bulletin de la Société Géologique de France 169, 281-299. 
Sosson, M., Rolland, Y., Muller, C., Danelian, T., Melkonyan, R., Kekelia, S., Adamia, S., Babazadeh, V., Kangarli, T., Avagyan, A., Galoyan, G., Mosar, J., 2010. Subductions, obduction and collision in the Lesser Caucasus (Armenia, Azerbaijan, Georgia), new insights. In: Sosson, S., Kaymakci, N., Stephenson, R., Bergerat, F., Starostenko, V. (Eds), Sedimentary Basin Tectonics from the Black Sea and Caucasus to the Arabian Platform. Geological Society of London, Special Volume 340, 329-352.

Strougo, A., Faris, M., Haggag, M. A. Y., Radwan, A., Gingerich, P.D., 2013. Planktonic foraminifera and calcareous nannofossil biostratigraphy through the middle to late Eocene transition at Wadi Hitan, Fayum Province, Egypt. Contributions from the Museum of Paleontology, University of Michigan 32, 111-138.

Toumarkine, M., Luterbacher, H., 1985. Paleocene and Eocene planktic foraminifera. In: Bolli, H. M., Saunders, J.B., Perch-Nielsen, K. (Eds.), Plankton Stratigraphy, Volume 1.Cambridge University Press, Cambridge, p. 87-154.

Veguni, A.T., 1964. Middle Eocene nummulite stratigraphy of the Southern Armenia. Voprosy geologii Kavkaza. Akademiya Nauk Armyanskoi SSR, Yerevan, 216, 56-62 (in Russian).

Veguni, A. T., 1978. Paleogene of Armenia and adjacent territories. $\mathrm{PhD}$ thesis abstract. Lviv, Lviv States University, $48 \mathrm{p}$.

Wade, B.S., 2004. Planktonic foraminiferal biostratigraphy and mechanisms in the extinction of Morozovella in the late Middle Eocene. Marine Micropaleontology 51, 23-38.

Wade, B.S., Al-Sabouni, N., Hemleben, C., Kroon, D., 2008. Symbiont bleaching in fossil planktonic foraminifera. Evolutionary Ecology 22, 253-265.

Wade, B.S., Pearson, P.N., Berggren, W.A., Pälike, H. 2011. Review and revision of Cenozoic tropical planktonic foraminiferal biostratigraphy and calibration to the geomagnetic polarity and astronomical time scale. EarthScience Reviews 104, 111-142.

Wade, B.S., Premec-Fucek, V., Kamikuri, S., Bartol, M. Luciani, V., Pearson, P. N., 2012. Successive extinctions of muricate planktonic foraminifera (Morozovelloides and Acarinina) mark the base Priabonian. Newsletters on Stratigraphy 45, 245-262.

Wei, W., Wise Jr., S. W., 1990. Biogeographic gradients of middle Eocene-Oligocene calcareous nannoplankton in the South Atlantic Ocean. Palaeogeography, Palaeoclimatology, Palaeoecology 79, 29-61.

Zakrevskaya, E., Shcherbinina, K., Hayrapetyan, F., 2014. The Bartonian and Priabonian boundaries in southern Armenia: problems and solutions. Field trip guide book. VNII Geosystem, Moscow, p. 49.

Zijderveld, J.D.A., 1967. AC demagnetization of rocks: analysis of results. In: Collinson, D.W., Creer, K.M. (Eds.), Methods in Paleomagnetism. Elsevier, Amsterdam, p. 254-286.

Manuscript received: January 24, 2016; rev. version accepted: May 19, 2015.

\section{Appendix}

\section{List of planktonic foraminifera}

Acarinina collactea (Finlay)

Acarinina echinata (Bolli)

Acarinina medizzai (Toumarkine and Bolli)

Catapsydrax dissimilis (Cushman and Bermudez)

Catapsydrax unicavus Bolli, Loeblich and Tappan

Chiloguembelina spp.

Dentoglobigerina galavisi (Bermudez)

Dentoglobigerina cf. tripartita (Koch)

Globigerina officinalis Subbotina

Globigerinatheka index (Finlay)

Globigerinatheka luterbacheri Bolli

Globigerinatheka mexicana (Cushman)

Globigerinatheka semiinvoluta (Keijzer)

Globigerinatheka tropicalis (Blow and Banner)

Globorotaloides eovariabilis Huber and Pearson

Globorotaloides quadrocameratus Olsson, Pearson and Huber

Hantkenina alabamensis Cushman

Hantkenina primitiva (Cushman and Jarvis)

Jenkinsina spp.

Parasubbotina hagni (Gohrbandt)

Pseudohastigerina micra (Cole)

Pseudohastigerina naguewichensis (Myatliuk)

Steptochilus sp.

Subbotina angioporoides (Hornibrook)

Subbotina corpulenta (Subbotina)

Subbotina eocaena (Guembel)

Subbotina gortanii (Borsetti)

Subbotina jacksonensis (Bandy)

Subbotina linaperta (Finlay)

Subbotina senni (Beckman)

Subbotina utilisindex (Jenkins and Orr)

Subbotina yeguaensis (Weinzierl and Applin)

Turborotalia cerroazulensis (Cole)

Turborotalia cocoaensis (Cushman)

Turborotalia pomeroli (Toumarkine and Bolli)

Turborotalita quinqueloba (Natland)

\section{List of calcareous nannofossils}

Bicolumnus ovatus Wei \& Wise 1990

Blackites spinosus (Deflandre and Fert, 1954) Hay and Towe 1963

Chasmolithus altus Bukry and Percival 1971

Chiasmolithus grandis (Bramlette \& Riedel, 1954) Radomski, 1968

Chiasmolithus oamaruensis (Deflandre in Deflandre \& Fert, 1954) Hay, Mohler \& Wade 1966 
Coccolithus biparteoperculatus (Varol, 1998) Bown and Dunkley Jones

Coccolithus formosus (Kamptner, 1963) Wise 1973

Coccolithus pelagicus(Wallich, 1877) Schiller 1930

Corannulus germanicus Stradner 1962

Cribrocentrum erbae Fornaciari et al. (2010)

Cribrocentrum isabellae Fornaciari et al. (2010)

Cribrocentrum reticulatum Perch-Nielsen 1971

Cyclicargolithus floridanus Bukry, 1971

Dictyococcites bisectus Bukry \& Percival 1971

Dictyococcites filewiczii Wise and Wiegand in Wise 1983

Dictyococcites stavensis Varol 1988

Discoaster barbadiensis (Tan SinHok, 1927) Bramlette \& Riedel 1954

Discoaster deflandrei Bramlette and Riedel, 1954

Discoaster nodifer (Bramlette and Riedel, 1954) Bukry 1973

Discoaster saipanensis Bramlette \& Riedel 1954

Discoaster tani Bramlette \& Riedel 1954

Helicosphaera bramlettei (Müller, 1970) Jafar \& Martini 1975

Helicosphaera compacta Bramlette \& Wilcoxon1967

Helicosphaera reticulata Bramlette and Wilcoxon 1967

Isthmolithus recurvus Deflandre in Deflandre \& Fert 1954

Lanternithus minutus Stradner 1962

Reticulofenestra hillae Bukry \& Percival 1971

Reticulofenestra lockeri Müller 1970

Reticulofenestra umbilica (Levin, 1965) Martini \& Ritzkowsky 1968

Sphenolithus moriformis (Bronnimann \& Stradner, 1960) Bramlette \& Wilcoxon 1967

Sphenolithus predistentus Bramlette \& Wilcoxon 1967

Sphenolithus radians Deflandre in Grassé 1952

Sphenolithus predistentus Bramlette \& Wilcoxon1967

Sphenolithus pseudoradians Bramlette \& Wilcoxon1967

Umbilicosphaera bramlettei (Hay and Towe, 1963) Bown et al. 2007

Zygrhablithus bijugatus (Deflandre in Deflandre \& Fert, 1954) Deflandre 1959

\section{List of larger benthic foraminifera}

Nummulites maximus d'Archiac, 1850

Nummulites incrassatus de la Harpe, 1883

Nummulites variolarius (Lamarck, 1804)

Nummulites orbignyi (Galeotti, 1837)

Nummulites chavannesi de la Harpe, 1878

Nummulites striatus (Bruguière, 1792)

Nummulites stellatus Roveda, 1961

Nummulites boulangeri Schaub, 1981

Nummulites biarritzensis d'Archiac, 1837, emend. d'Archiac, 1852

Nummulites pulchellus Hantken in de la Harpe, 1883

Nummulites garnieri de la Harpe in Boussac, 1911

Nummulites budensis Hantken, 1875

Nummulites cunialensis Herb \& Hekel, 1975

Nummulites anomalus de la Harpe, 1877

Nummulites fichteli Michelotti in de la Harpe, 1883

Nummulites fabianii (Prever in Fabiani, 1905)

Assilina schwageri (Silvestri, 1928)

Assilina alpina (Douvillé, 1916)

Operculina bericensis Oppenheim, 1896

Operculina gomezi Colom \& Bauzá, 1950

Heterostegina reticulata Rütimeyer, 1850

Heterostegina reticulata Rütimeyer, 1850 multifida

(Bieda, 1949)

Heterostegina reticulata Rütimeyer, 1850 helvetica Kaufmann, 1867

Spiroclypeus sirottii Less \& Özcan, 2008

Pellatispira madaraszi (Hantken, 1876)

Biplanispira absurda Umbgrove, 1938

Discocyclina augustae augustae Weijden, 1940

Discocyclina radians (d'Archiac, 1850) labatlanensis

Less, 1987

Discocyclina dispansa (Sowerby, 1840)

Nemkovella strophiolata (Gümbel, 1870) tenella

(Gümbel, 1870)

Asterocyclina stella (Gümbel, 1861) praestellaris

(Brönnimann, 1940)

Asterocyclina alticostata (Nuttall, 1926)

Asterocyclina stellata (d'Archiac, 1846)

Orbitoclypeus varians (Kaufmann, 1867)

Silvestriella tetraedra (Gümbel, 1870)

Fabiania cassis (Oppenheim, 1896)

Chapmanina gassinensis (Silvestri, 1905)

Sphaerogypsina globula (Reuss, 1848) 